\title{
African swine fever virus eradication in Africa
}

\author{
Mary-Louise Penrith ${ }^{\text {ab,*, }}$, Wilna Vosloo ${ }^{\text {ac }}$, Ferran Jori ${ }^{\text {de }}$, Armanda D. S. Bastos ${ }^{\mathrm{e}}$
}

${ }^{\text {a }}$ Department of Veterinary Tropical Diseases, 0110 University of Pretoria, South Africa

${ }^{\mathrm{b}}$ TADScientific, Pretoria, South Africa

${ }^{c}$ Australian Animal Health Laboratory, Geelong, Vic., Australia

d UPR AGIRs, ESDepartment, CIRAD, Campus Intemational de Baillarguet, 34398 Montpellier, France

${ }^{\mathrm{e}}$ Mammal Research Institute, Department of Zoology and Entomology, 0002 University of Pretoria, South Africa

*Corresponding author. Tel. +27 12342 1514; fax +27 124302192. E-mail address:

marylouise@vodamail.co.za(M.L Penrith)

\section{Abstract}

African swine fever was reported in domestic pigs in 26 African countries during the period $2009-2011$. The virus exists in an ancient sylvatic cycle between warthogs (Phacochoerus africanus) and argasid ticks of the Ornithodoros moubata complex in many of the countries reporting outbreaks and in two further countries in the region. Eradication of the virus from the countries in eastern and southern Africa where the classic sylvatic cycle occurs is clearly not an option. However, the virus has become endemic in domestic pigs in 20 countries and the great majority of outbreaks in recent decades, even in some countries where the sylvatic cycle occurs, have been associated with movement of infected pigs and pig meat. Pig production and marketing and ASF control in Africa have been examined in order to identify risk factors for the maintenance and spread of ASF. These include large pig populations, traditional free-range husbandry systems, lack of biosecurity in semi-intensive and intensive husbandry systems, lack of organisation in both pig production and pig marketing that results in lack of incentives for investment in pig farming, and ineffective management of ASF. Most of these factors are linked to poverty, yet pigs are recognised as a livestock species that can be used to improve livelihoods and contribute significantly to food security. The changes needed and how they might be implemented in order to reduce the risk of ASF to pig producers in Africa and to the rest of the world are explored.

Keywords: African swine fever; Asfivirus; domestic pigs; management; sub-Saharan Africa; sylvatic cycle

\section{Introduction}

African swine fever (ASF) is caused by a unique DNA virus (Asfivirus), the only member of the family Asfarviridae. It is endemic in most countries in sub-Saharan Africa where pigs are kept (Penrith et al., 2004a; Penrith and Vosloo, 2009). It is arguably the most important constraint for pig production in Africa, not only due to high mortality periodically causing devastating losses, but also because the fear of it discourages investment in pig production (Foueré, 2007). Because there is no vaccine and no treatment, it is most often perceived in endemic areas as a disease that cannot be prevented or cured and therefore has to be tolerated. The presence of ASF virus (ASFV) in domestic pigs on the African continent poses a continual threat to the rest of the world, as has been demonstrated by the introduction of the disease into three other continents within a period of 50 years (Costard et al., 2009b; Penrith and Vosloo, 2009). Although eradication of ASFV from its 
natural hosts and vectors in Africa is not an option, eradication of ASFV in domestic pigs may theoretically be achievable, provided that pigs are managed in a way that excludes contact with the sylvatic sources of infection and prevents maintenance of the virus in domestic pig populations. The question of whether eradication of ASFV from domestic pigs would constitute freedom from the disease highlights a paradox in international approaches to control of diseases involving wild hosts. While for certain epidemic diseases (e.g. classical swine fever, Newcastle diseases, notifiable avian influenza) the international standards set by the World Organisation for Animal Health (OIE) focus on eradication from livestock populations only, no clear distinction between infection in domestic and wildlife populations is made for other diseases, e.g. foot and mouth disease and ASF (OIE, 2012a). The existence of ASFV in a sylvatic cycle involving warthogs (Phacochoerus africanus) (Jori et al., this volume; Penrith et al., 2004a; Thomson, 1985) is not considered to pose a serious direct risk to the rest of the world but will always need to be borne in mind when designing pig management systems in Africa.

In order to assess the feasibility of eradicating ASFV from domestic pigs in Africa and if possible, to propose a strategy that could achieve this, this review examines the risk factors for its maintenance and spread among domestic pigs. These include the evolution and current status and distribution of ASF in domestic pigs in Africa and the epidemiological factors relevant to eradication, focusing on pig production and marketing in Africa as the major factors that will determine whether ASFV can be eradicated from domestic pigs. Current approaches to control of ASF are also explored, as inappropriate control measures can contribute to spread and maintenance of this and other diseases. As it is likely that eradication, if feasible, will be a long term process, approaches to managing ASF in domestic pigs in ways that are appropriate for sub-Saharan Africa, which includes some of the poorest countries in the world, are explored.

\section{Historical and current distribution of ASF in Africa}

ASF was first observed in settlers' pigs in Kenya in 1909 and was reported by Montgomery (1921) as an entity distinct from classical swine fever. Reports of ASF in South Africa (Steyn, 1928, 1932) and Angola (Câmara, 1933) followed. While Câmara was able to determine that the disease observed in pigs was not erysipelas, as previously thought, but was caused by a virus, its identity as the disease described by Montgomery in East Africa was only confirmed in 1943 (Mendes, 1994). In Kenya and South Africa ASF affected pigs that belonged to settlers of European origin, but in Angola pigs were also kept by the indigenous population and it was noted that those pigs showed increased resistance to ASF and that they appeared to serve as a source of infection for the pigs farmed by the Portuguese settlers (Mendes, 1994). After World War II the potential for producing pigs in the central highlands of Angola to provide meat for a burgeoning pork processing industry was recognised. ASF 
was proving a major constraint for pig production and a special section for research on pig diseases was established at the Central Veterinary Laboratory in Nova Lisboa (now Huambo), where attempts to develop a vaccine were undertaken from 1950 (Mendes, 1994).

Incursions of ASF into Europe focused attention on the disease. There were two separate episodes in Portugal in 1957 and again in 1960 (Wilkinson, 1989), with subsequent establishment of ASF in the Iberian Peninsula and spread to other countries in Europe as well as the Caribbean and Brazil. During the same period ASF was also reported from Malawi (Matson, 1960) and Mozambique (Abreu et al., 1962; Mendes, 1971). A link between warthogs (Phacochoerus africanus) and ASF was recognised early in East Africa (Montgomery, 1921), but the possible involvement of an arthropod vector was only confirmed much later (Plowright et al., 1969), after Sánchez Botija (1963) reported the involvement of the argasid tick Ornithodoros erraticus in the epidemiology of ASF in Spain. Investigations in a number of countries in southern and eastern Africa revealed infection in Ornithodoros moubata complex ticks inhabiting both warthog burrows and pig shelters (Penrith et al., 2004a) but wild pigs were not investigated in Angola (Mendes, 1994) or in Mozambique, although Mendes (1971) suggested that the source of the disease, first observed in Mozambique in 1954, might be warthogs from a neighbouring country. It has recently been confirmed that infected warthogs and O. moubata complex ticks are present in the central parts of Mozambique (Quembo, Jori, Dwarka, Ntshali, Souto, Pereira, Heath, Vosloo, unpublished data) and most likely elsewhere in the country.

By the mid 1970s ASF had been reported either in warthogs or domestic pigs or both from most countries in southern and eastern Africa (Penrith et al., 2004a). Studies undertaken in Malawi revealed an endemic situation in domestic pigs in Mchinji District in the south-eastern part of the country bordering on Mozambique and Zambia, with large numbers of infected Ornithodoros ticks living in shelters in which the pigs were confined at night (Haresnape and Mamu, 1986; Haresnape and Wilkinson, 1989; Haresnape et al., $1985,1987,1988)$. No evidence for warthog involvement was found in that area.

Scott (1965) described all the countries known to have significant warthog populations as being at high risk of ASF, including Mali, which has an insignificant domestic pig population. Although the first official report to the World Animal Health Organisation (OIE) of ASF in West Africa was from Senegal in 1978 (Plowright et al., 1994), a 1959 virus isolate from Dakar (Bastos et al. 2003), indicates that the virus was introduced a good deal earlier. Two temporally unrelated outbreaks occurred in Cameroon in 1982 and 1985 (Awa et al., 1999; Ekue and Wilkinson, 1990; Nana-Nukechap and Gibbs, 1985), and genetic characterisation of the viruses from Cameroon was suggestive of a 'reverse introduction' of the virus from the Caribbean to Cameroon (Wesley and Tuthill, 1984). Investigations in both countries indicated that the sylvatic cycle was apparently not involved in either Senegal or Cameroon (Ekue and Wilkinson, 1990; Sarr and Diop, unpublished report, 1990), and recent investigations have confirmed this hypothesis in Senegal (Jori et al., this volume). 
During the 1990s there appeared to be a sharp increase in ASF activity throughout sub-Saharan Africa. ASF was reported for the first time south of the Save River in Mozambique in 1993 and for the first time in more than 30 years in Kenya in 1994 (Penrith et al., 2004a). In 1996 an outbreak of ASF in Côte d'Ivoire (CIV) heralded a pandemic that affected new countries in the region (Benin, Togo, Nigeria, Ghana and Burkina Faso) from 1997 to 2003, with increased outbreaks reported in Senegal, Gambia and Cape Verde during the same period (Penrith et al., 2004a). With the exception of CIV, it has not been eradicated from any of these countries. In 1998 ASF was reported for the first time from the island of Madagascar, where it has since become endemic (Costard et al., 2009a; Roger et al., 2001). The only recently-infected African countries from which ASF has been eradicated, or apparently eradicated, are CIV (El Hicheri et al., 1998) and the small island nations of São Tomé e Principe, which suffered an outbreak in 1979 (Lage and Oliveira da Silva, 1980, quoted by Wesley and Tuthill, 1984), and Mauritius, which suffered an outbreak in 2007 that was eradicated by 2008 (Lubisi et al., 2009). Although Ghana succeeded in eradicating ASF within a year after its introduction in 1999, it has since 2002 suffered repeated outbreaks either resulting from incursions from its endemically infected neighbours or because the disease has become endemic. In the period 2009-2011, 26 countries have reported outbreaks or the endemic presence of ASF in domestic pigs. Additionally, the sylvatic cycle in warthogs remains present in Botswana and Zimbabwe, but no outbreaks in domestic pigs were reported during that period, meaning that there are currently 28 African countries infected with ASFV. The number of countries reporting ASF outbreaks has grown markedly since 1990 (Fig. 1), mainly as a result of new countries becoming infected (Penrith et al., 2004a). ASF is thus widespread in sub-Saharan Africa and has become endemic in domestic pigs in countries where the sylvatic cycle occurs and in a number of countries that were newly infected in the last two decades (Fig. 2).

\section{Epidemiological factors relevant to ASFV eradication in Africa}

ASFV is maintained in three overlapping cycles in Africa: a sylvatic cycle involving a commensal relationship between the common warthog, Phacochoerus africanus, and an argasid tick of the Ornithodoros moubata complex, the eyeless tampan usually known as $O$. porcinus that lives in their burrows; a cycle in domestic pigs involving $O$. porcinus that lives in pig shelters; and a cycle involving only domestic pigs without, as far as has been established to date, either wild Suidae or tampans (Etter et al., 2011; Jori and Bastos, 2009; Jori et al., this volume; Penrith et al., 2004a, Penrith and Vosloo, 2009). Endemically infected countries fall into three main categories: countries where sporadic outbreaks occur or have occurred historically owing to transmission from warthogs to domestic pigs by O. porcinus (Botswana, Kenya, Namibia, South Africa, Tanzania, Zimbabwe); countries where infection is present in warthogs but the disease has also become endemic in populations of domestic pigs (Congo-Brazzaville, Mozambique, Malawi, Uganda, Zambia; Angola, Burundi, Democratic Republic of Congo (DRC) and Rwanda most probably fall into this category as well); and countries where the disease was apparently introduced later and circulates or is endemic in domestic pigs (Benin, Burkina Faso, Cameroon, Cabo Verde, Gambia, Ghana, Guinea Bissau, Madagascar, Nigeria, Senegal, Togo), with 
possible occasional spill-over to wild suids (Luther et al. 2007a, b). Central African Republic and Chad have recently reported outbreaks close to the border with Cameroon that were attributed to illegal movement of infected pigs from Cameroon (OIE, 2012c).

There is little published information about the status and epidemiology of ASF in West Africa. Senegal and Nigeria are two countries for which more information has been produced in recent years (Etter et al., 2011; Fasina et al., 2010; Luther et al., 2007a,b; Owolodun et al., 2010a,b; Taylor et al., 1977; Vial et al., 2006, 2007). In Senegal, the disease is known to be endemic, with more than 54 outbreaks reported to the OIE since 1986 (Etter et al., 2011). Although Senegal is predominantly Muslim, the pig population is far from being negligible and has increased in size over the years. It is mainly located in the Southern Casamance, which is predominantly Christian (Missohou et al., 2001), but also in areas where the presence of expatriates has increased the demand for pork meat such as Dakar, Saint Louis or the Sine Saloum Region (Etter et al., 2011). There is now evidence that the sylvatic cycle in Senegal plays at most a limited role ASF maintenance in wild hosts (Jori et al., this volume; Vial et al., 2007). Transmission between domestic pigs within a domestic cycle therefore seems to be the main source of recurrent re-emergence of the disease in this country. This is particularly true in Lower Casamance (Southern Casamance), where despite the absence of potential wild hosts for ASF the disease is endemic with the highest prevalence in the country (Etter et al., 2011). The reason for this is the widespread occurrence of free ranging farming systems. ASF has also become endemic in domestic pigs in Nigeria since its introduction in 1997, and occurrence of a sylvatic cycle there has not been established (Luther et al., 2007a,b; Owolodun et al., 2010b).

Although the sylvatic cycle involving warthogs occurs throughout southern and eastern Africa (the western and northern limits are not well established), the great majority of ASF outbreaks in recent decades have been associated with the movement of infected domestic pigs and pork rather than the sylvatic cycle (Penrith and Vosloo, 2009). Outbreaks in Botswana, Namibia, South Africa and Zimbabwe have invariably been associated with warthog contact. Zimbabwe has not reported any outbreaks since 1992. Outbreaks in Kenya were historically associated with warthogs but the outbreaks in recent decades have been attributed to movement of infected pigs from the border with Uganda. Investigation of recent outbreaks in domestic pigs in Tanzania suggests that some may have been caused by transmission from the sylvatic cycle but others have likely been due to movement of infected pigs from neighbouring countries (Misinzo et al., 2010; Wambura et al., 2006). However, the importance of the sylvatic cycle is twofold. Firstly, the ineradicable presence of ASFV in natural reservoirs means that measures based on an in-depth understanding of the cycles involving natural reservoirs will always need to be implemented to ensure that domestic pigs are not exposed to them (Jori and Bastos, 2009). The potential for the development of new sylvatic or pig/tick cycles, for example in West Africa, also requires further investigation (Etter et al., 2011; Luther et al., 2007a,b; Owolodun et al., 2010b), particularly as some ASF genotypes have expanded beyond their traditional ranges (Gallardo et al. 2011) and intra-continental incursions, which are now easier to track with genetic methods and the establishment of an 
extensive reference database, are increasingly reported (Gallardo et al. 2011; Gonzague et al. 2001; Lubisi et al. 2009). Secondly, the sylvatic cycle in warthogs is associated with rich genetic diversity of ASFV (Bastos et al., 2003; Boshoff et al., 2007; Lubisi et al., 2005; Nix et al., 2006). This may have implications if a vaccine is developed.

The introduction of ASFV into other continents and most probably into West Africa is generally agreed to have resulted from movement of infected pork products (Costard et al., 2009b; Penrith et al., 2004a; Wilkinson, 1989). The main focus for eradication in domestic pigs therefore requires the identification of pig-related factors that have allowed ASF to become established in areas distant from the classic sylvatic cycle as well as in many of the countries where the sylvatic cycle occurs but is not the primary cause of outbreaks. These factors relate to the size of the pig population and the ways in which pigs in Africa are managed, fed and marketed, as well as measures, if any, that are used to control ASF.

The role of recovered pigs or pigs that do not develop clinical signs as 'long term carriers' is frequently cited as being important in the maintenance of ASFV (Fasina et al., 2010; Jori and Bastos, 2009; Olugasa et al., 2009a), but there is no evidence that viraemia with shedding of infective virus persists for longer than 30 days in a healthy recovered pig; virus may be recovered from lymphoid tissues for a few months, and viral DNA may be detected in lymphoid tissues for longer (Penrith et al., 2004b; Pujols-Romeu et al., 1991b; Valadão, 1969; Wilkinson et al., 1983). A serologically negative boar introduced into a group of 16 healthy serologically positive pigs approximately six weeks after an outbreak of ASF had occurred in their quarantine facility remained in close contact with the group for three years without seroconverting or developing any signs of ASF. This suggests that persistence of infectivity in healthy recovered pigs is unusual, if it does occur at all (Penrith et al., 2004b), in contrast to the chronically diseased pigs that occurred in Spain following infection with viruses of lower virulence (Sánchez-Vizcaíno et al., 2012). Surveillance performed by detection of antibodies and/or viral genome can be deceptive, since neither antibodies nor viral nucleic acid necessarily indicate active infection. Antibodies persist for long periods of time; Pujols-Romeu et al. (1991a) determined a half-life of 1.8 years. It is likely that some transmission may occur from recently recovered pigs or their tissues, but much more evidence is needed to confirm an important role for long-term carrier pigs in the maintenance and spread of ASF. However, ASF infection burns out when there are no longer any naïve pigs left to infect; large high-contact pig populations provide a never-ending supply of naïve pigs and can likely maintain circulation of ASFV indefinitely, as has apparently occurred in Sardinia between wild boar and free-ranging domestic pig populations (Rolesu et al., 2007).

\section{Pig population size and ASF}

Pigs in Africa account for only 3.06\% of the world's pig population and $2 \%$ of global pork production, 
although the number of pigs increased almost threefold between 1980 and 2010 (FAOSTAT, 2011) (Figs 3, 4). The efficiency of data collection undoubtedly varies among countries and many of the statistics are extrapolations from earlier figures. Techniques for gathering statistics have probably improved so that the increase in the pig population over time could partially be due to more pigs being counted, but it is generally accepted that Africa accounts for less than 5\% of the world pig population. Growth of pig production has accompanied population growth and urbanisation, particularly in West Africa, in response to increased demand for affordable protein (FAO, 2012a; Fasina et al., 2010; Kagira et al., 2010a; Mopate Logtene and Kabore-Zoungrana, 2010; Phiri et al., 2003; Youssao et al., 2008); it is also being encouraged in countries like Nigeria and Uganda to improve food security and the protein intake of the population (Muhanguzi et al., 2012; Nwanta et al., 2011; Ogunniyi and Ajao, 2011; Onyenweaku and Effiong, 2005). Nevertheless, available data indicate that the off-take in terms of pork is extremely low. The official figures probably represent only a fraction of the pork consumed because the amount of meat produced is in general based on slaughter figures, and the majority of pigs in Africa are slaughtered locally without being recorded (FAO, 2012a,b; Phiri et al., 2003; Pondja et al., 2010; Sikasunge et al., 2007; Veary and Manoto, 2008). This is important because the probability of pork that is locally slaughtered and consumed being a direct source of infection for other continents is extremely low, but the likelihood that it plays a role in the maintenance and transmission of ASFV in local pig populations is high.

As indicated in Section 2, the first official reports of ASF for a number of countries where the warthog cycle occurs or probably occurs only emerged after ASF arrived in Europe. There is therefore relatively little information about ASF in domestic pigs before 1960. However, infection in domestic pigs in these areas probably coincided with their introduction into Africa (Penrith et al., 2004a,b). The evolution of a cycle in domestic pigs that involves hut-dwelling Ornithodoros in some of these countries in areas without warthogs suggests a long-term association between domestic pigs and ASFV. However, there is little doubt that the introduction of ASF into countries in West Africa where the sylvatic cycle in warthogs has not been demonstrated to occur was a later event (El Hicheri et al., 1998; Owolodun et al., 2010a,b; Penrith et al., 2004a). While the date of introduction of ASF into Cabo Verde, Guinea Bissau and Senegal is unknown but believed to be as early as 1959 and could be much earlier, the infection of other countries appears to be correlated with recent increases in the population of pigs (Figs 5,6). The outbreaks in Cameroon that started in 1982 followed a period during which the number of pigs in Cameroon had virtually doubled (FAOSTAT, 2011). Among the countries with 500,000 or more pigs (Fig. 7), only Zimbabwe reported no outbreaks of ASF between 2000 and 2011. Two of the 10 countries with between 100,000 and 500,000 pigs have never reported ASF (Gabon and Liberia). No information about ASF status was submitted to OIE by Liberia for either the period 1996 - 2004 or 2005 - 2012 (OIE, 2012b,c). Gabon indicated an uncertain status in 1997 (OIE, 2012b), following which no information was submitted until 2006, after which negative reports for ASF have been submitted (OIE, 2012c). Six of the 14 countries with 10,000 - 50,000 pigs and none of the countries with fewer than 10,000 pigs 
reported ASF between 2000 and 2011. With two exceptions, none of the countries with fewer than 10,000 pigs have ever reported ASF. A report of an outbreak of ASF in Algeria in 1939 (Scott, 1965) is difficult to credit because it occurred prior to the introduction of ASF into Europe. If it was indeed ASF the most likely source of infection would be swill from a ship that had taken infected pork on board at a port on the East African coast or Angola. The 1979 outbreak in São Tomé e Principe may have been due to an introduction from Europe, as suggested for the introduction into Cameroon (Wesley and Tuthill, 1984). The status of Equatorial Guinea prior to 2009 is unknown, but since 2009 negative reports have been submitted to OIE.

There is therefore a clear relationship between the size of the pig population and the probability of the country becoming infected with ASF, and large pig populations or an increase in the number of pigs appear to be risk factors for ASF. This is a matter of some concern, as obviously growth of the pig population is necessary for growth of the industry. When ASF is present in a country more outbreaks are likely when there are large pig populations with high contact rates because these populations offer an unending source of naïve pigs to infect so that outbreaks are not self-limiting, potentially resulting in rolling outbreaks that can persist for long periods of time. The main reason why explosive growth of the pig population appears to favour introduction of ASF is probably that more pigs are sourced from infected neighbouring countries with obvious effects, which may not be the case when the pig population is small. The risk of large pig populations can therefore not be separated from the risks posed by disorganised pig production and marketing; these are simply magnified as pig population size increases.

\section{Pig production systems in Africa}

The modest figures for pig production do not reflect the importance of the contribution that pigs make to food security and household income in a large number of countries in sub-Saharan Africa, although it is recognised that this is small compared with the potential that pig production has to improve livelihoods and provide an affordable source of high quality protein in the region (Almeida and Cardoso, 2008a,b; Chiduwa et al. 2008; Halimani et al., 2012; Ironkwe and Amefule, 2008; Kagira et al., 2010a,b; Karimuribo et al., 2011; Lekule and Kyvsgaard, 2003; Mashatise et al., 2005; Moreki and Mphinyane, 2011; Mopate Logtene and Koussou, 2003; Muhanguzi et al., 2012; Ndébi et al., 2004, 2009; Nsoso et al., 2006; Petrus et al., 2011; Wabacha et al., 2004; Youssao et al., 2008).

Pig farming systems in sub-Saharan Africa may be classified into traditional systems, in which pigs are free ranging or at most confined at night and/or seasonally to protect the crops, and semi-intensive and intensive systems, in which the pigs are mostly confined (Figs 8 - 12). Many of the semi-intensive farms are backyard farms in peri-urban areas; large-scale intensive pig farms are the 
exception rather than the rule. In the majority of countries most pigs are kept in traditional systems that generally make use of local breeds of pigs or their crosses that are hardy and undemanding in terms of nutrition and management (Lekule and Kyvsgaard, 2003) (Fig. 13). Productivity is generally low but, because the investment is low, the price received for the pig is usually higher than the cost of producing it, so the system is seen as profitable, although at subsistence level (Verhulst, 1993). On the other hand, commercial pig production using improved breeds of pigs or even local breeds has often proven unprofitable and unsustainable owing to high input costs that include housing, feed and infrastructure and market prices that are too low to justify the investment (Chabo et al., 2000; Lekule and Kyvsgaard, 2003; Verhulst, 1993).

In spite of difficulties and failures reported in some countries, there is considerable support for improving pig production by intensification, partly to satisfy the demand for affordable protein in urban areas that are growing exponentially, and partly to increase the profitability of pig production as part of the general imperative to alleviate poverty (Ampaire and Rothschild, 2010; Lekule and Kyvsgaard, 2003; Verhulst, 1993). Even in countries where for religious or other reasons pig meat is not widely consumed, small scale pig production is increasing and is not discouraged because of the contribution it can make to livelihoods and food security (Abdu and Gashaw, 2010). Apart from low productivity, traditional pig farming systems have disadvantages, some of which increase as countries modernise. Pigs are destructive and can become a cause of conflict when crops and gardens are damaged; heavy losses may be experienced among free-ranging pigs with access to modern roads with fast traffic; and porcine cysticercosis is increasingly recognised as a major public health problem in communities where pigs have access to human waste (Assana et al., 2001; Ganaba et al., 2011; Phiri et al., 2003; Pondja et al., 2010; Sikasunge et al., 2007). Free-ranging pigs are at increased risk of exposure to ASF both through the sylvatic cycle and through contact with pigs from other herds and with infected material (FAO, 2012a,b; Muhanguzi et al., 2012; Penrith et al., 2007; Penrith and Vosloo, 2009). An investigation in two districts in south-western Malawi after severe outbreaks of ASF in 1989 revealed that losses were far lower in the district where the majority of pigs were permanently penned (Allaway et al., 1995). Free-ranging pig populations provide the necessary level of contact for circulation of ASFV to be maintained indefinitely if the pig population is large enough (Penrith et al. 2004a,b).

ASF is recognised as a major limiting factor for pig production in sub-Saharan Africa, but the most serious constraints that have been identified in many countries are lack of suitable feed at affordable prices, poor or no access to animal health services, cost of housing pigs, poor genetics of breeding stock and lack of knowledge and information about pig production and health (Adesehinwa et al., 2003a; FAO, 2012a,b,c; Halimani et al., 2007; Ironkwe and Amefule, 2008; Kagira et al., 2010b; Karimuribo et al., 2011; Mashatise et al., 2005; Moreki and Mphinyane, 2011; Muhanguzi et al., 2012; Mutua et al., 2011; Nwanta et al., 2011; Petrus et al., 2011). These constraints become critical with intensification of pig production, when pigs are permanently confined and completely dependent on their owners for all aspects of their wellbeing. High feed prices and low quality of available feed have been identified as a major constraint for smallholder and commercial 
farmers in many African countries (Chabo et al., 2000; Garcês et al., 1998; Karimuribo et al., 2011; Lekule and Kyvsgaard, 2003; Moreki and Mphinyane, 2011; Verhulst, 1993). Lack of resources to feed pigs is a major contributory factor to the maintenance of extensive pig-farming systems (FAO, 2012b; Matos et al., 2011; Muhanguzi et al., 2012; Ndébi et al., 2009; Ngowi et al., 2007; Petrus et al., 2011). Even in semi-intensive systems where pigs are in theory permanently housed they may be liberated for shorter to longer periods during the day to forage for themselves (Costard et al., 2009a; Muhanguzi et al., 2012; Mutua et al., 2011; Nissen et al., 2011).

Pig shelters with earth floors and with the type of walls that provide crevices in which Ornithodoros can hide occur throughout sub-Saharan Africa (Figs 14,15). Because the ticks spend most of their time off the pigs and away from exposed surfaces in dark places, acaricides have proven to be of little value in controlling them, and it is necessary to burn the structures in order to be rid of the ticks (Penrith et al., 2004a). Lack of resources to construct proper housing for pigs is a frequently stated constraint for producers, and therefore pig housing that offers shelter to Ornithodoros is likely to be a limiting factor for managing ASF in some areas.

When pigs are permanently confined, they are often at risk of ASF and other infectious diseases owing to poor or no biosecurity and poor hygiene. Lack of affordable feed results in housed pigs being fed kitchen waste, which is most often from the household but if available may include kitchen waste from restaurants and other sources (Costard et al., 2009a; Missohou et al., 2001). This in turn poses a risk as ASF may be spread via food products containing contaminated meat (Costard et al., 2009a; Penrith et al., 2004a; Penrith and Vosloo, 2009).

The main risk factors for ASF associated with pig production systems are therefore increased exposure to infection in free-ranging husbandry systems and lack of basic biosecurity in semi-intensive and intensive husbandry systems, which may include feeding of kitchen waste that could include uncooked or undercooked pork. In areas where a cycle between pigs and tampans exists or where species of Ornithodoros are or could be associated with pigs, housing pigs in structures that offer a suitable habitat for the ticks is an additional risk factor.

\section{Pig marketing in Africa}

Pig marketing has a twofold importance in an assessment of how ASF can be controlled in pigs in sub-Saharan Africa. Firstly, it is evident that current marketing practices play an important role in the spread of ASF. Secondly, markets that are discerning in terms of product quality and that pay good prices for a consistent supply of healthy pigs would provide the strongest (possibly the only) incentive for modernising and improving pig production. In Kenya access to higher value markets for smallholder pig farmers has been a major incentive for better farming practices and growth of the industry (FAO, 2012c; Kagira et al., 2010a; Wabacha et al., 2004). However, in countries like South Africa and Zimbabwe, with a small but highly developed commercial pig 
industry, there is a dualist marketing system, with little or no integration of the traditional and smallholder pig farming sectors into the markets that are accessed by the larger-scale commercial producers (Antwi and Seahlodi, 2011; Madzimure et al., 2012), although smallholder pig farmers are sometimes able to access the higher value markets if they can produce pigs of the required quality (Madzimure et al., 2011). Factors that exclude most smallholder producers from the higher value market include distance from the markets and the fact that they use breeds that do not conform to what the market requires, as well as sanitary considerations and inconsistency of supply (Antwi and Seahlodi, 2011; Chimonyo et al., 2010; Kagira et al., 2010a,b; Madzimure et al., 2012; Missohou et al., 2001; Phiri et al., 2003). Where demand for pigs and pork is high, local markets may offer conditions that pig producers perceive to be satisfactory (Karimuribo et al., 2011; Nsoso et al., 2006).

Studies in Africa indicate that most if not all pig producers keep pigs partly or entirely for income generation; another important reason for keeping pigs is as a source of funds for emergencies and a hedge against inflation (Ajala, 2007; Awa et al., 1999; Bosma et al., 2004; FAO, 2012a,b,c; Costard et al., 2009a; Ironkwe and Amefule, 2008; Kagira et al., 2010b; Karimuribo et al., 2011; Missohou et al., 2001; Mopate Logtene and Kabore-Zoungrana, 2010; Muhanguzi et al, 2012; Mutua et al.; 2011; Ndébi et al., 2004; Nsoso et al., 2006; Petrus et al., 2011; Wabacha et al., 2004; Youssao et al., 2008). Mashatise et al. (2005) reported that the majority of producers of indigenous pigs in north-eastern Zimbabwe kept them as a source of meat, but this appears to be unusual; a survey in southern Zimbabwe and in Limpopo and Eastern Cape provinces of South Africa indicated that the main reason for keeping pigs was income generation and that consumption of pig meat tended to be reserved for special or ceremonial occasions (Halimani et al., 2012). In Guinea Bissau it was reported that pigs are of importance for food security and in some areas are the most frequently marketed livestock species, but their consumption is also often linked to ceremonies (Almeida and Cardoso, 2008a,b).

In spite of their motive being income generation, poor and disorganised marketing systems in most countries prevent pig producers from realising good prices for their product (Ajala and Adesehinwa, 2007; FAO, 2012a,b,c; Kagira, 2010a,b; Moreki and Mphinyane, 2011; Muhanguzi et al., 2012; Ndébi and Ongla, 2006; Petrus et al., 2011). Factors that contribute to inefficiency are the lack of weighing facilities, so that the price is fixed by estimation and agreement; selling dictated by the needs of the seller e.g. in response to some urgent domestic need; buyers fixing prices well below production costs; market fluctuations resulting in over-supply or scarcity; the involvement of a number of players along the value chain from producer to consumer; and lack of market information (Antwi and Seahlodi, 2011; Ajala and Adesehinwa, 2007; Ampaire and Rothschild, 2010; FAO, 2012a,b,c; Kagira et al., 2010a,b; Moreki and Mphinyane, 2011; Ndébi and Ongla, 2006; Petrus et al., 2011).

A major cause of market fluctuation in traditional systems is the seasonal need to confine free-ranging pigs to prevent damage to crops. Most of the pigs are sold before they have to be confined and fed since at that time little feed is available, so that supply of pigs far exceeds demand (FAO, 2012a). Large numbers of pigs are reported to be sold in DRC at times when an increase in pig diseases is expected (FAO, 2012b). Other factors that 
influence the market seasonally are periods when large festivals or lack of other meat due to pastoralist migrations in the dry season increase the demand for pork (Ajala and Adesehinwa, 2007). These fluctuations in the supply of pigs deprive traditional systems of the consistency that is required by higher priced markets. ASF outbreaks also have a marked effect on the market by causing a shortage of pigs (FAO, 2012a,b; Kagira et al., 2010a). The tendency to sell pigs when the first cases of ASF appear in a herd has been documented in several African countries and is a major factor in spread of ASF (Babalobi et al., 2007; Costard et al., 2009b; Fasina et al., 2010; Mendes, 1994; Penrith et al., 2007). It is often associated with a drop in price of pork, as large numbers of pigs become available and this can be exacerbated by consumer resistance to buying meat that may be infected (Babalobi et al., 2007; FAO, 2012a; Nana-Nukechap and Gibbs, 1985). With time, pigs become scarce, demand for pork exceeds supply and the price of pork escalates (FAO, 2012a; Nana-Nukechap and Gibbs, 1985).

Marketing of live pigs at local sales or through speculators is common in Africa for various reasons including high transaction costs (transport, slaughter and storage fees) (Ajala and Adehesinwa, 2007; Antwi and Seahlodi, 2011; FAO, 2012a,b; Ndébi and Ongla, 2006; Nsoso et al., 2006) (Fig. 16). It has been shown that better margins are usually realised for fresh or cooked meat than for live pigs (Ndébi et al., 2004; Nsoso et al., 2006), although some pig keeping communities sell mainly live pigs (Ganaba et al., 2011; Ndébi and Ongla 2006). This may be associated with lack of slaughter facilities close to where the pigs are produced and lack of transport (FAO, 2012b; Muhanguzi et al., 2012), and also leads to large numbers of pigs being slaughtered without inspection at informal venues (Assana et al., 2001; Awa et al., 1999; FAO 2012a,b; Kagira et al., 2010a; Mutua et al., 2011).

Well-developed marketing channels that link traditional pig farming systems to city markets have developed in some areas, such as an area shared by north-eastern Cameroon and southwestern Chad. In 1982, following outbreaks of ASF in commercial piggeries in the south of Cameroon, traditional pig farmers were able to take advantage of the shortage of pork because a strong marketing network existed in the area (Koussou and Duteurtre, 2002). The network made provision for bringing in pigs from Chad as required. The leaner local-breed pigs proved popular with clients in the major cities and there was therefore no incentive to improve upon the ancient traditional free range production system, in spite of the fact that a high level of porcine cysticercosis was reported in the area (Assana et al., 2001). The incentive may be provided, however, by outbreaks of ASF that started in north-eastern Cameroon in 2009 and spread to Central African Republic and Chad in 2010 (OIE, 2012c). A similar network was observed in Togo along the border with Benin, where live pigs were moved from local markets to the capital, Lomé, and across the border to Cotonou in Benin, where prices were reported to be higher than in Togo (C. Bebay and M.-L. Penrith, personal observation, 2009). These marketing networks enable producers to obtain better prices than those paid at local points of sale. However, live pig markets, speculators that buy pigs from multiple farms and movement of live pigs over distances have the potential to spread ASF (Babalobi et al., 2007; Costard et al., 2009b; Etter et al., 2011; Fasina et al., 2010, 2012; Misinzo et al., 2010; Olugasa and Ijagbone, 2007; Owolodun et al., 2010a,b; Wambura et al., 2006; 
Wieland et al., 2011).

Formal markets where pork that emanates from pigs slaughtered in an abattoir and subjected to meat inspection exist in at least the major cities of most African countries. However, the needs of the most discerning retailers and consumers (supermarkets, expatriates and tourist facilities) are often not met by these markets owing to issues of health and quality of the product and are instead satisfied by imported pork. For example, in Mauritius, one of the most developed countries in the region, which is highly dependent on tourism, the pig abattoir does not have a grading system or cutting facilities, and the result is that there is no price differentiation between high and low quality pigs and the type of pork product sought by processors, hotels and restaurants is not produced locally and must be imported (J.T.R. Robinson, personal communication 2010). Even in cities pigs are often slaughtered under far from adequate or hygienic conditions, as described for Burkina Faso (FAO, 2012a), Cameroon (Ndèbi and Ongla, 2006), Kenya (Kagira et al., 2010a), and Nigeria (Ajala and Adesehinwa, 2007), a situation that is common in many developing countries (Kagira et al,. 2010a) (Figs 17,18). The poor conditions are due to various factors including lack of a reliable electricity supply, lack of running water and ignorance on the part of the managers, and they contribute to a lack of profitability in the pig industry.

The main risk factors posed by marketing systems are lack of organisation, low incentives for improving pig production, live pig markets, and lack of proper slaughter facilities and reliable meat inspection, particularly at local level but often even at higher levels in the value chain. A recent study in Nigeria has indicated that the presence of a slaughter facility in the neighbourhood is significantly associated with the risk of pig farms being infected with ASF owing to a high level of contamination because infected pigs are often presented for slaughter (Fasina et al., in press).

\section{Current management of ASF in sub-Saharan Africa}

While ASF was eradicated in the majority of non-African countries that suffered outbreaks of ASF, only three countries in the sub-Saharan African region have apparently succeeded in eradicating ASF (São Tomé e Principe, CIV, and Mauritius). These countries suffered only a single incursion each, there is no evidence of maintenance in a sylvatic cycle in any of them, and two of them are small island nations with low numbers of pigs. The recent cases of CIV and Mauritius are described briefly.

The first cases in CIV were registered in the largest city, Abidjan, in April 1996, and the last reported cases occurred in October 1996. Factors that favoured eradication in CIV included the discontinuous distribution of pigs, relatively low pig numbers and the fact that at the time none of the countries that share borders with CIV (Liberia, Guinea, Mali, Burkina Faso, Ghana) were infected. Success was attributed to highly effective awareness campaigns carried out across the country as part of an FAO Emergency Technical Cooperation Project, a detailed epidemiological enquiry and stamping out of all the pigs in the Greater Abidjan region (approximately half of the pigs in the country) (El Hicheri et al., 1998). While it was clear that the 
awareness campaigns helped to limit dangerous practices on the part of producers that spread ASF, the contribution of the massive culling operation is more ambiguous. It eliminated most of the backyard pigs in the slums where the outbreak was believed to have started, but it also eliminated large numbers of unaffected commercial herds farmed under conditions of acceptable biosecurity, causing widespread discontent and heavy financial losses in spite of compensation. The epidemiological survey revealed that some outbreaks in rural areas had occurred as a result of pigs moved out of the Greater Abidjan area to avoid the control measures, a likely result of compensation being paid at one third of market value (MLP, personal observation, 1996). ASF has apparently not been reintroduced in spite of its frequent occurrence in neighbours Ghana since 1999 and Burkina Faso since 2003 and the fact that CIV has experienced considerable civil unrest since 2000. However, the last negative report to OIE was for the second half of 2008 (OIE, 2012c).

In Mauritius the first cases of unusual pig mortality were detected in June 2007. Classical swine fever was suspected because an incursion of that disease had occurred in 2000 and was eradicated by 2002 using vaccination. According to information obtained from state veterinarians and pig farmers in April 2008 widespread vaccination of pigs against CSF was undertaken (Penrith, 2008), which may have spread the disease. Mortalities continued and ASF was officially confirmed in October 2007 (Lubisi et al., 2009). Biosecurity measures, movement control of pigs and pig products and closure of the abattoir were implemented. Modified stamping out was also implemented until March 2008 and more than 10,000 pigs were slaughtered. In lieu of compensation, 'soft' loans were made available to farmers who lost their pigs to ASF or culling. These measures succeeded in the control and successful eradication of the disease, the last outbreak having been reported in July 2008. Since then, no further cases have occurred and the event was reported to be resolved (OIE, 2009). The absence of a sylvatic cycle and the enforcement of legislation that forbids the keeping of pigs unless they are permanently confined facilitated eradication. A population of feral pigs, descended from domestic pigs introduced by sailors in the $16^{\text {th }}$ century (Oliver and Brisbin, 1993), is small, scattered and confined to hunting estates, feedlots or small farms, making maintenance of viral circulation virtually impossible.

Where the classic sylvatic cycle exists, measures that prevent contact between pigs and the sylvatic hosts of ASFV have proven highly effective in preventing outbreaks of ASF. These measures have been applied with success in Kenya, South Africa, Zimbabwe, Botswana and Namibia although sporadic outbreaks have been reported due to inadequate implementation of the separation measures (Penrith et al., 2004a). This underlines the fact that human behaviour is the most important factor in the management of ASF. Focal outbreaks resulting from accidental exposure of domestic pigs to infected ticks have been eradicated by strict quarantine measures and stamping out. As the number of pigs has generally been small this has been successful, assisted in some cases by compensation or 'goodwill payments' in spite of the fact that the pigs involved were clearly not contained according to the legislation. In all of these countries traditional free-range pig keeping is largely restricted to particular areas, which in South Africa are mostly distant from the infected (controlled) area. The commercial pig industries of Kenya, South Africa and Zimbabwe are well developed and the pigs are farmed under 
reasonable to excellent conditions of biosecurity. Nevertheless, Kenya since 1994 and South Africa in 2012 have experienced outbreaks related to illegal pig movements in spite of the control measures in place.

Control in countries where the disease is endemic and pigs are the main source of infection is much more difficult. The situation has been exacerbated by porous borders as more countries have become infected. Conditions in Ghana are not dissimilar to those in CIV. The initial outbreaks in Ghana were eradicated with the assistance of stamping out of infected herds with market-related compensation supplied by donor funding, with fairly good cooperation from pig owners. However, within two years ASF was re-introduced from the infected neighbours and has likely become endemic at least in some areas. Togo and Benin also initially attempted stamping out, but compensation became unsustainable in Togo as the infection spread rapidly through the large pig population, and initial resistance to stamping out by pig farmers in Benin until compensation became available meant that it was implemented too late to prevent the disease from becoming endemic.

In addition to stamping out, quarantine and movement control must be rigorously applied during ASF outbreaks. While most newly affected countries decreed movement bans and bans on the sale of pork, with closure of abattoirs and butcheries, and some of them instituted road blocks on main roads, the measures were largely ineffective because it was impossible to enforce them. Heavy road traffic, alternative off-road routes between villages, the small size and portability of pigs, the ease with which pork from slaughtered pigs could be concealed among other produce, and the fact that producers were unwilling or unable to confine their pigs and wait for the authorities to come and kill them were just some of the factors that made enforcement impossible. Once ASF becomes endemic there is usually little or no effort to implement control measures and more often than not farmers do not report the disease. Lack of discipline on the part of producers is one of the major challenges for control of ASF.

According to our observations, the implementation of simple biosecurity measures by individual pig farmers has proven effective in protecting the pigs in a number of countries affected by ASF outbreaks in recent years, and was reported for well managed farms in Cameroon during the 1982 outbreaks (Nana-Nukechap and Gibbs, 1985). Fasina et al. (in press) confirmed that a lack of certain biosecurity measures on pig farms in Nigeria is positively associated with ASF infection.

The involvement of Ornithodoros ticks in a cycle with domestic pigs obviously complicates control. In areas where this cycle has been demonstrated in Africa no attempts have been made to achieve control or eradication. The ability of the ticks to remain infective for long periods was demonstrated by an outbreak that occurred in Portugal in 1999, five years after ASF had been eradicated, and was traced to Ornithodoros erraticus in pig shelters that were re-occupied after a lengthy period without pigs (Boinas et al., 2011). The presence of the ticks is strongly linked to lack of resources to provide the type of pig housing that does not offer suitable habitats for them. 


\section{Strategy development for management of ASF in sub-Saharan Africa}

What needs to be in place to enable improved management, if not eradication, of ASF in domestic pigs in Africa?

- Structured, organised and vertically integrated pig industries with defined value chains from producers to consumers.

- Animal disease risk management through the implementation of biosecurity measures at all stages of the value chains. These measures would include effective separation between domestic pigs and wild hosts and modernisation of husbandry systems. The measures would need to be developed to mitigate the major risks for ASF infection in the area where they were to be applied.

- Outbreak control strategies that are appropriate to the situation and feasible to implement.

These elements of the strategy need to be developed and implemented in parallel as they are complementary. In exploring them research needs are identified as well as the incentives that exist for change and the level of support that would be required for pig producers, as they are the main players in the strategy. It must be recognised that outbreak control can never be guaranteed and that the major focus should be on prevention ASF. It is also recognised that, given the constraints imposed by poverty on the majority of pig producers in Africa, structuring of the industry and application of strict biosecurity measures is not likely to be applicable across the board, and that alternative strategies may be necessary to manage ASF in traditional husbandry systems. One possible approach that should be explored further is discussed briefly in Subsection 8.4.

\subsection{Organisation of the pig industry}

Jahnke (1982) examined pig production systems in tropical African countries in the context of livestock development strategy and concluded that advanced and stratified pig breeding systems should be the long-term pig production strategy for tropical Africa, as elsewhere. Changing pig husbandry practices is a long term goal, particularly in countries with a lengthy tradition of keeping pigs. It is understandable that poor farmers are unwilling to change from a very low input system to a system that requires investment of resources, even in terms of effort (Perry and Grace, 2009). The strongest incentive to move from free-range to more intensive pig production would be for the latter to become demonstrably more profitable by ensuring better market prices while keeping production costs as low as possible.

\subsubsection{Reducing production costs}


The most prevalent constraints for pig production as identified in Section 4 are lack of resources to provide housing for pigs, high feed costs/low feed availability and quality, low productivity, poor access to animal health services, and lack of knowledge and information. Addressing them will involve:

- Providing/improving access to micro-finance for pig farmers to invest in their pig farming operations.

- Providing minimum standards and plans for pig housing using low- to no-cost local materials and as far as possible improving on current housing in terms of hygiene and security.

- Making the existing information on alternative, locally usable feedstuffs available to pig farmers and promoting research on alternative sources of nutrition for pigs in order to encourage local feed production.

- Encouraging the use of local breeds or half breeds that have good qualities in terms of hardiness, lower feed and water requirements, and good mothering, while improving productivity by better health care and feed management.

- Developing strategies to reduce inbreeding that, where practical, would include artificial insemination with fresh semen.

- Improving animal health care through farmer training and making basic health services available through community-based animal health workers in areas where veterinary services are not easily accessed.

- Providing farmers with information about pig production, health and marketing through improved extension services including farmer-to-farmer extension.

- Establishing close linkages with programmes that support improved pig husbandry to improve food security and income for women, provide more protein for urban markets, and control zoonoses, in particular porcine cysticercosis.

\subsubsection{Improving profitability through improved marketing strategies and opportunities}

Disorganised marketing of pigs has been identified as a major constraint for pig farmers throughout sub-Saharan Africa. Problems diagnosed are availability and quality of infrastructure for slaughtering and processing pigs, low prices, market fluctuations resulting in price fluctuations, high transaction costs, lack of suitable transport, and long marketing chains involving many actors. Addressing these challenges will involve:

- Establishing minimum standards for pig slaughtering facilities (abattoirs and slaughter slabs) in terms of welfare, hygiene and meat inspection and as far as 
possible making them available in areas where pigs are produced through provision of micro-finance to local entrepreneurs.

- Educating farmers and traders in the determination of fair prices.

- Stabilising the market by ensuring, or enabling the farmers to ensure, a consistent supply of feed, preventing ASF outbreaks through implementation of good biosecurity, and correlating supply of pigs with periods of known high demand.

- Establishing standards for the transport of pigs; access to micro-finance to enable producers and entrepreneurs to comply with the standards.

- Training and employing meat inspectors at slaughter slabs.

- Analysing market chains and eliminating unnecessary actors or changing their roles.

- Implementing systems for grading pig carcasses to ensure that producers are paid more for producing good quality pigs.

- Providing support for pork processors to add value to products and enable local products to compete with imported pork.

\subsection{ASF risk mitigation along value chains}

The concept of animal disease risk mitigation along value chains has been the subject of a recent publication by FAO (2011). The approach requires analysis and mapping of value chains. Much of this information already exists for particular areas or pig production systems but more analysis will be needed and should be targeted at areas where ASF is prevalent. The approach advocated by FAO is based on risk assessment at each step of the value chain to determine what mitigation measures will be needed and whether they will be cost-effective and proportionate to the risk. Because ASF is a highly contagious and lethal disease, it can be accepted that the risk of an outbreak is not acceptable and measures must be put in place to prevent it. Therefore, HACCP (Hazard Analysis and Critical Control Points) could be used to identify the points along the value chains at which mitigation is critical and what form it should take. Some examples are given in Table 1, but each country or region would need to adapt the process to its own identified value chains, e.g. in areas where ASFV is maintained by Ornithodoros ticks inhabiting pigsties, special measures would be required. This approach, routinely used to ensure food safety, is not widely used in animal disease control, but has the potential to ensure both animal health and food safety in an integrated way from the farmer to the final product (Thomson, Penrith, Atkinson and Thalwitzer, unpublished results). 
The identification of pork products that would be unable to transmit ASFV, even if an asymptomatic but infected pig had been slaughtered, e.g. products processed by exposure to high enough temperature for a sufficient length of time to inactivate the virus, can further mitigate the risk of spreading ASFV via infected pork (Thomson et al., 2004).

\subsection{Appropriate and feasible outbreak control strategies}

The conventional approach to controlling an outbreak of ASF by applying strict quarantine and movement control and then culling all infected and in-contact pigs works best when there is a single focus, the pigs are contained and their number is known, and full cooperation is ensured by market-related compensation (Penrith and Thomson, 2004; Penrith and Vosloo, 2009). Additionally, there should be a suitable, secure place and adequate resources (earth-moving equipment, quick lime and/or sufficient materials to ensure complete incineration) for the total destruction of the carcasses. Prerequisites for the measures to succeed are early diagnosis, a clearly defined area in which movement can be controlled, and a well-resourced veterinary service that can be mobilised rapidly. Late diagnosis with the development of multiple foci and lack of resources to implement control measures effectively have been the norm in Africa. Once the disease has spread and particularly where free-ranging pigs are involved, culling is likely to cause suffering to poor people who might otherwise not have lost their pigs while being ineffective in containing the disease. Even when owners are generously compensated for pigs culled, as occurred in the Eastern Cape Province of South Africa after classical swine fever was introduced in 2005, producers may be unwilling to cooperate and the negative effects on producers and the local economy may outweigh the advantages of eradicating a disease by massive, area-based culling (Madzimure et al., 2012; Penrith et al., 2011). The dynamics of subsistence farming are different from those of commercial farming and should be understood before embarking upon any large scale or drastic disease control measures (Costard et al., 2009a; Perry and Grace, 2009).

Recognising that ineffective control can have worse results than none at all, the main focus should be on achieving farmer-based control, implemented by farmers who are serious about protecting their pigs and not spreading the disease and who can serve as examples to others.

\subsection{Resistance to ASF}

Domestic pig populations that demonstrate increased resistance to the pathogenic effects of ASFV have been well described (Haresnape et al., 1985, 1987; Penrith et al., 2004b; Valadão, 1969). An attempt to identify the genetic basis of resistance in a population of pigs in Mozambique suggested that the resistance is not simply inherited and may be linked to epidemiological factors in their area of origin (Penrith et al., 2004b). The study did confirm Valadão's (1965) study which found that recovered pigs from a neighbouring district 
were not infectious to naïve pigs in close contact with them and would therefore not pose a high risk for transmission of ASF, although virus might persist in some lymphoid tissues for some time (Wilkinson, 1984). Pigs that are not affected by ASFV would clearly be an asset in endemic areas where poverty prevents pig owners from changing to modern husbandry practices. However, currently only approximately $40 \%$ of the populations investigated demonstrate this innate resistance, with a wide range of variation, so that heavy losses are still experienced during outbreaks. Further research is needed to elucidate the nature of the observed resistance and to determine whether it would be possible to achieve entire resistant populations that could be maintained in traditional systems without increasing the risk of ASF.

\section{Discussion}

The majority of ASFV incursions into non-African countries in the last century were eradicated, although always at a high cost and, in the case of the Iberian Peninsula, it took more than 30 years (Bech-Nielsen et al., 1993; Boinas et al., 2004; Costard et al., 2009b; Lyra, 2006; Moura et al., 2010; Sánchez-Vizcaino et al., 2012). Sardinia remains endemically infected (Rolesu et al., 2007). The situation in the Caucasus and Russia remains unresolved since the introduction of the virus in 2007 and is considered to pose a grave threat globally (Sánchez-Vizcaíno et al., 2012).

The approach used in Europe, the Caribbean and Brazil was stamping out of infected and sometimes of in-contact herds, with compensation. In the Iberian Peninsula maintenance of ASFV in Ornithodoros erraticus prolonged the campaign (Boinas et al., 2004, 2011; Pérez-Sánchez et al., 1994; Wilkinson, 1984), and persistence in Sardinia is associated with circulation of the virus in some areas in wild boars and populations of free-ranging pigs (Rolesu et al., 2007). Brazil appears to have mounted one of the most successful eradication campaigns; only 66,902 pigs were culled, as opposed to more than 500,000 in Cuba and the entire pig populations of Haiti and Dominican Republic (Moura et al., 2010). Although the Brazilian situation was more favourable in the absence of complicating factors like wild hosts, vectors, and infected neighbours with porous borders, there are lessons for Africa in the Brazilian approach. The pig farmers participated fully in decision-making processes and there was a strong focus on improving pig health by better disease control in general. As a result, not only was ASF eradicated by 1984 but it left the Brazilian pig industry modernised and stronger than it had been before (Lyra, 2006; Moura et al., 2010).

The eradication of ASFV from the African continent is impossible because of its maintenance in wildlife. The killing of wildlife in order to control or eradicate diseases that affect livestock, in particular trypanosomosis, has in the past been undertaken in some parts of Africa (Connor and Van den Bossche, 2004) but current approaches to biodiversity conservation would rightly exclude such practices, apart from the fact that when they were applied they were not particularly successful. Scott (1965) indicated that the destruction of warthogs and bushpigs as an eradication measure was 'expensive, difficult and often ineffective', and this was before the involvement of Ornithodoros had been reported in Africa. However, if the international standards 
for ASF could be brought into line with those for classical swine fever, where freedom can be recognised in domestic livestock in spite of circulation in wildlife, this issue would be resolved.

In those countries in which a sylvatic cycle exists and poses the greatest threat to pig producers, physical separation of pigs from wild suids and their associated ticks has proven to be effective (Penrith et al., 2004a; Penrith and Vosloo, 2009). The implementation of these measures is based on the identification of a control zone, the extent of which is primarily determined by the distribution of ASF-positive Ornithodoros ticks and warthogs. Many of the surveys used for control zone demarcation were conducted in the 1970s and 1980s, and have not been assessed since. A recent study has highlighted the possibility for the virus to disappear from a tick reservoir population (Arnot et al. 2009), emphasising the value of regular monitoring as maintenance of control zones is costly and can have high costs and negative impacts on pig farmers in the control areas. Furthermore, as climate change impacts on vector distribution (Sutherst, 2001), and as land use practices are particularly dynamic in Africa (Ellis and Galvin, 1994), it is also possible that new areas of infection may unwittingly become established outside of control zones (Fig. 19). The availability of highly sensitive, molecular-based methods (Bastos et al., 2009) makes is possible to assess ASF status of Ornithodoros reservoir populations in a cost-effective manner, thereby ensuring that limited resources are concentrated in the areas that most require implementation of control measures, and that communities that are no longer at risk of ASF can farm and trade without undue restrictions. Similar surveys are also of value in countries to which ASF has been introduced to domestic pigs and which have naive wild suid and tick populations in which the virus may become established, as it will ensure that additional control measures are put in place to limit the threat, and in areas where a tick/domestic pig cycle is established to determine whether they may be expanding or contracting over time.

In most African countries the major dynamic for maintenance and spread of ASF in Africa has shifted from the classic sylvatic cycle to the way domestic pigs are produced and marketed. Eradicating or at least improving the management of ASF in domestic pigs in Africa would enhance the contribution that raising pigs could make to poverty reduction. To improve the potential of livestock as a way out of poverty, three pathways have been identified, namely reducing vulnerability, improving productivity performance and improving market access (Perry et al., 2002; Perry and Grace, 2009). ASF increases vulnerability by causing high mortality and also by reducing productivity performance and restricting access to higher value markets.

Free-range pigs in traditional systems are recognised as a high risk for ASF (FAO, 2012a,b,c; Muhanguzi et al., 2012; Penrith et al., 2007; Penrith and Vosloo, 2009; Scott, 1965). However, a number of studies have shown that traditional pig farming systems in Africa are more cost effective and therefore more sustainable than modern systems, which are not profitable mainly due to high feed costs (Chabo et al., 2000; Lekule and Kyvsgaard, 2003; Verhulst, 1993). Verhulst (1993) described externally funded projects intended to improve 
pig production that failed spectacularly in several African countries while traditional pig farming systems flourished. It is probable that some if not all of the projects described failed because they did not respond to a need felt by local pig producers, or take into account important issues that influence production in resource-poor communities (Mashatise et al., 2005). Nevertheless, apart from the imperative to manage ASF, other forces such as population growth, urbanisation and land use pressure are strong incentives for changing from traditional extensive to intensive pig production systems (Nwanta et al., 2011).

Intensification of pig production is recognised to have improved control and management of diseases like erysipelas and classical swine fever as well as zoonotic diseases that are found in outdoor pigs (Perry et al., 2011). Surveillance results for six regions in Nigeria by Fasina et al. (2010) showed the lowest incidence of ASF-positive pigs in Southeast Nigeria. A survey of pig production in three Southeast Nigerian states, including one of those surveyed for ASF and found negative, indicated that pigs were mostly confined and owners reported no ASF (Nwanta et al, 2011). Since traditional systems have other disadvantages including low productivity and a high risk of porcine cysticercosis, there is increasing pressure on producers to change to a system in which pigs are permanently confined (Assana et al., 2001; Githigia et al., 2005; Kagira et al., 2010a,b; Lekule and Kyvsgaard, 2003; Nsoso et al. 2006; Phiri et al., 2003; Pondja et al., 2010).

Although nutrition becomes a major problem when pigs are confined permanently, some strategies are available to assist pig farmers to improve the economy of their enterprises by making use of locally available feedstuffs including agricultural by-products and waste products, improving the quality of local feedstuffs by inexpensive additives or making the most of feeds to fatten pigs when those feeds are abundant (Adesehinwa, 2008; Akinfala and Tewe, 2004; Bosma et al., 2004; Halimani et al., 2007; Peters, 2008). The choice of breed can also influence feeding costs. Traditional pig farming systems make use of local pig breeds because they are hardy and undemanding in terms of management, feed and even water (Chimonyo et al., 2010; Halimani et al., 2012; Ncube et al., 2003). Indigenous breeds are reported to have a better ability to digest fibre and to have lower protein requirements than improved pig breeds (Anugwa and Okwori, 2008; Chimonyo et al., 2010; Codjo, 2003; Halimani et al., 2010; Madzimure et al., 2012).

Low productivity in traditional husbandry systems is often attributed to the genetics of local pigs. However, a number of studies have shown that the productivity of local pig breeds can be considerably improved by better management, genetic selection and judicious cross breeding (Chimonyo et al., 2010; Darfour-Oduro et al., 2009; Ncube et al., 2003) without losing the advantage of their relative hardiness. Using local breeds or crosses rather than modern breeds in semi-intensive systems that offer permanent confinement might reduce the profitability gap between traditional and more modern pig production (Chimonyo et al., 2010; Verhulst, 1993).

Strengthening animal health service provision in the region is important to achieve more profitable pig farming. This can be achieved by farmers to recognise signs of disease in their pigs (Fig. 20) and training 
members of the community to provide primary animal health care at affordable rates. Although directed at serving pastoralists in the Horn of Africa, practical approaches to improving animal health services and thereby safe trade in animal products have been proposed by Catley et al. (2004) and Perry and Sones (2008) that would be applicable in the context of ASF control in Africa as well. Investment in pig health by traditional and smallholder producers in Africa is generally low (Huttner et al., 2000; Mashatise et al., 2005; Nsoso et al., 2006) and is correlated with level of education and commitment, which are generally associated with better management (Adesehinwa et al., 2003a,b; Ajala, 2007; Nwanta et al. 2011; Ogunniyi and Ajao, 2011; Youssao et al., 2008), although one study in Nigeria showed no correlation between technical efficiency and education (Onyenweaku and Effiong, 2005).

Organisation of the pig industry starts with developing and/or empowering pig farmer associations, even small groups at local level, which can grow into an over-arching national body that can have considerable influence and contribute importantly both to the growth of the sector and to disease management. Pig farmer organisations in Burkina Faso and Kenya and some other countries have achieved modest progress for the industry but organisation is needed on a much wider scale (FAO, 2012a,c). Partnerships between commercial and smallholder/traditional livestock producers can result in rapid progress towards an organised and vertically integrated industry but this has not been widely practised so far (Perry and Grace, 2009).

The sharp rise in pig numbers, particularly in West and East Africa, in the 1980s and 1990s occurred in response to a demand for affordable meat for rapidly growing urban populations (Adesehinwa, 2008; FAO, 2012a,c; Owolodun et al., 2010b; Phiri et al., 2003; Youssao et al., 2008). The demand for pork in cities is met largely by smallholder to large scale commercial farming of pigs in areas with easy access to city markets (FAO, 2012a,b,c; Mopate Logtene and Kabore-Zoungrana, 2010; Wabacha et al., 2004; Youssao et al., 2008). It has been reported in Sierra Leone that pigs are mainly reared intensively by producers who want to have full control over their pigs in order to increase productivity (Anon, 2011). In a pilot study conducted in two districts in Mozambique, smallholder pig farmers in a district close to the capital city of Maputo where a good market existed for their pigs were more willing to invest in their pigs than farmers in a remote rural district with endemic ASF, where the only available market was local (Penrith et al., 2007). With few exceptions pig farmers in rural areas are not able to access city markets for reasons described in Section 6. Some of the constraints that have been identified can be overcome by access to quality extension services that provide the necessary production and marketing information and forming cooperatives to be able to sell more pigs (Antwi and Seahlodi, 2011; Olugasa et al., 2009b). Improving market infrastructure, providing local facilities and services, and ensuring acceptable hygiene in slaughter and marketing facilities at all levels would stimulate industry development and promote investment in pigs in order to satisfy market demand and make pig farming more profitable.

Managing ASF in Africa requires some investment on the part of pig farmers. The recognition of the 
involvement of warthogs in ASF outbreaks resulted in requirements for farmers to construct pig-proof facilities if they wished to raise pigs in affected areas (De Kock et al., 1940; Plowright et al., 1994). Similarly, where the threat of ASF comes from domestic pigs and their products, farmers have to adopt simple but adequate biosecurity measures to exclude infection (Fasina et al., 2012; Olugasa et al., 2009b; Penrith et al., 2007; Penrith and Vosloo, 2009). Limited but useful information is available about the cost of implementing biosecurity to prevent ASF on smaller pig farms. A recent study indicated that the implementation of simple biosecurity measures to prevent ASF on a 122-sow farrow-to-finish unit in Nigeria would be profitable in spite of the costs of the measures (Fasina et al., 2012). Some cost benefit studies have been carried out on control of porcine cysticercosis (Ngowi et al., 2007); the pig management aspects are identical to those for ASF. Wieland et al. (2011) developed a model to assess the impact of mitigation measures to prevent spread after introduction of ASF into an ASF-free region. It may be useful to develop similar models to assess the impact of mitigation measures proposed to reduce spread and maintenance in endemic situations in domestic pigs.

Even if Africa experiences a major swing from traditional and smallholder pig production to intensive production, there is no guarantee that this will become permanent. The pig industry is subject to fluctuations in supply and times of over-supply will generally see many smallholder producers going out of business, but this situation can rapidly be reversed, as occurred in Thailand, where after the Asian financial crisis from 1997 - 2000 it was believed that smallholder pig activity at village level no longer existed; by 2007 these activities had resurged to a level of $25 \%$ of total output (Psilos, 2007). It is therefore necessary to explore all the factors needed for better management of ASF.

There are several other factors that could potentially assist in eradicating the disease. A better understanding of the epidemiology of ASF in each country or region is needed to prepare informed control strategies based on control along value chains. This should also include region-specific knowledge on the impact and role of the sylvatic cycle, as well as cycles between domestic pigs and Ornithodoros if present (Jori et al., this volume). Trading patterns and factors that impact on movement of pigs and their meat should also be studied at country and regional level, and projects focusing on these aspects are to be encouraged.

Although ASF causes high mortality which facilitates recognition, an early and accurate diagnosis is important to ensure that the correct control measures are applied within the shortest possible time. Most central laboratories in Africa are able to perform a diagnosis using a wide range of tests, but it is often difficult and time consuming to get the correct material to the laboratory and the result back to the field. Penside assays (Michaud et al., 2007) could play an important role in this regard, provided they are used under strict veterinary control where the reporting procedures are clearly defined.

The current lack of an effective vaccine limits the control options. Having such a vaccine 
would make a significant contribution to eradicating the disease from domestic pigs. Such a vaccine should be heat stable to ensure its efficacy on a continent with a tropical climate and often little access to cold storage and transport. In addition, it should be affordable to people who produce pigs as a cheap source of protein with a low profit margin and therefore cannot afford a vaccine at a cost that exceeds the profits. It should also provide lifelong immunity so that no revaccination with the resultant extra cost is necessary. Although most pigs have a short lifespan, it is important for farmers with breeding stock to have their animals protected for life, regardless of the quality of the animals.

Availability of pigs that are resistant to ASF would not only provide better economic stability to rural farmers, but could also assist in the eradication of the disease. However, despite reports of indigenous pigs being more resistant to disease (Mendes, 1994; Haresnape et al., 1987;

Nana-Nukechap and Gibbs, 1985), efforts to breed such pigs and reproduce the resistance observed in the field have not been successful but should be explored further (Penrith et al., 2004b). This aspect is being pursued using modern technologies such as RNAi.

\section{Conclusion}

The prevalence of traditional free-range pig production systems, to which conventional biosecurity measures cannot be applied, the lack of resources and financial incentives to adopt more modern systems, the existence of a sylvatic cycle with natural hosts able to maintain the virus in natural and pig farming habitats and the persistent circulation of ASF virus in high-contact domestic pig populations indicate that eradication and even effective management of ASF is at best a long-term goal. However, the combination of initiatives to foster smallholder and commercial pig production to satisfy the protein needs of growing urban populations, the potential for improving livelihoods offered by that demand, and growing pressure on producers to confine their pigs to protect both the pigs and society, may achieve a level of management of sufficient numbers of pigs to strongly reduce if not eliminate the occurrence of ASF.

\section{References}

Abdu, S., Gashaw, A., 2010. Production system dynamism and parasitic interaction of swine in and around Holetta, Ethiopia. Ethiop. Vet. J. 14, $71-81$.

Abreu, E.F. de, Valadão, F.B., Limpo Serra, J.J.B., Ornelas Mário, R., Sousa Montenegro, A., 1962. Peste suína africana em Moçambique. An. Serv. Vet. Moçamb. 8, 105 - 123.

Adesehinwa, A.O.K., 2008. Energy and protein requirements of pigs and the utilization of fibrous feedstuffs in Nigeria: a review. Afr. J. Biotech. 7 (25), 4798 - 4806. 
Adesehinwa, A.O.K., Aribido, S.O., Oyediji, G.O., Obiniyi, A.A., 2003a. Production strategies for coping with the supply and demand of pork in some peri-urban areas of Southwestern Nigeria. Livest. Res. Rur. Dev. 15 (10), http://www.lrrd.org//rrd15/10/ades1510.htm (accessed 30 April 2012).

Adesehinwa, A.O.K., Makinde, G.E.O., Oladele, O.I., 2003b. Socio-economic characteristics of pig farmers as determinant of pig feeding pattern in Oyo State, Nigeria. Livest. Res. Rur. Dev. 15 (12),

http://www.lrrd.org/lrrd15/12/ades1512.htm (accessed 30 April 2012).

Ajala, M.K., 2007. Analysis of factors affecting the management of pigs in Kaduna State, Nigeria. Agr. J. 2, 343 $-347$.

Ajala, M.K., Adehesinwa, A.O.K., 2007. Roles and efficiency of participants in pig marketing in the northern part of Nigeria. J. Cent. Eur. Agr. 8 (3), 311 - 326.

Akinfala, E.O. and Tewe, O.O., 2004. Supplemental effects of feed additives on the utilization of whole cassava plant by growing pigs in the tropics. Livest. Res. Rur. Dev. 16 (10),

http://www.lrrd.org/lrrd16/10/akin16082.htm (accessed 30 April 2012).

Allaway, EC., Chinombo, D.O., Edelsten, R.M., Hutchings, G.H., Sumption, K.J., 1995. Serological study of pigs for antibody against African swine fever virus in two areas of southern Malawi. Rev. sci. tech. Off. int. Epiz. $14(3), 667-676$.

Almeida, A.M. de, Cardoso, L.A., 2008a. Animal production and genetic resources in Guinea Bissau: I Northern Cacheu Province. Trop. Anim. Health Prod. 40 (7), 529 - 536.

Almeida, A.M. de, Cardoso, L.A., 2008b. Animal production and genetic resources in Guinea Bissau: II Tombali Province. Trop. Anim. Health Prod. 40 (7), 537 - 543.

Ampaire, A., Rothschild, M.F., 2010. Pigs, goats and chickens for rural development: Small holder farmer's experience in Uganda. Livest. Res. Rur. Dev. 22 (6), http://www.lrrd.org/lrrd22/6/ampa22102.htm (accessed 30 April 2012).

Anugwa, F.O.I and Okwori, A.I., 2008. Performance of pigs of different genetic groups fed varying dietary protein levels. Afr. J. Biotechnol. 7 (15), 2665 - 2670.

Anon, 2011. Feed efficiency in grower pig.

http://sulaimanbah.wordpress.com/2011/10/20/feed-efficiency-in-grower-pig/(accessed 28 May 2012).

Antwi, M., Seahlodi, P., 2011. Marketing constraints facing emerging small-scale pig farmers in Gauteng Province, South Africa. J. Hum. Ecol. 36 (1), 37 - 42. 
Arnot, L., du Toit, J.T., Bastos, A.D.S., 2010. Molecular monitoring of African swine fever virus using surveys targeted at adult Ornithodoros ticks: a re-evaluation of Mkuze Game Reserve, South Africa. Onderstepoort J. Vet. Res. 76 (4), 385-392.

Assana, E., Zoli, P.A., Sadou, H.A., Nguekam, Vondou, L., Pouedet, M.S.R., Dorny, P., Brandt, J., Geerts, S., 2001. Prévalence de la cysticercose porcine dans le Mayo-Danay (Nord-Cameroun) et le Mayo-Kebbi (sud-ouest du Tchad). Rév. Élev. Méd. Vét. Pays trop. 54 (2), 123 - 127.

Awa, D.N., Njoya, A., Ngo Tama, A.C., Ekue, F.N., 1999. The health status of pigs in North Cameroon. Rev. Élev. Med. vet. Pays trop. 52 (2), 93 - 98.

Babalobi, O.O., Olugasa, B.O.; Oluwayelo, D.O., Ijagbone, I.F., Ayoade, G.O., Agbede, S.A., 2007. Analysis and evaluation of mortality losses of the 2001 African swine fever outbreak, Ibadan, Nigeria. Trop. Anim. Health Prod. 39 (7), 533 - 542, doi:10.1007/s11250-007-9038-9.

Bastos, A.D.S, Arnot, L.F., Jacquier, M.D., Maree, S., 2009. A host species-informative internal control for molecular assessment of African swine fever virus infection rates in the African sylvatic cycle Ornithodoros vector. Med. Vet. Entomol. 23 (4), 399-409.

Bastos, A.D.S., Penrith, M.-L., Crucière, C., Edrich, J.L., Hutchings, G., Couacy-Hymann, E., Thomson, G.R., 2003. Genotyping field strains of African swine fever virus by partial $p 72$ gene characterisation. Arch. Virol. 148 (4), 693-706.

Bech-Nielsen, S., Perez Bonilla, Q., Sanchez-Vizcaino, J.M., 1993. Benefit-cost analysis of the current African swine fever eradication program in Spain and of an accelerated program. Prev. Vet. Med. 17 (3/4), 235 - 249.

Boinas, F.S., Hutchings, G.H., Dixon, L.K., Wilkinson, P.J., 2004. Characterization of pathogenic and non-pathogenic African swine fever virus isolates from Ornithodoros erraticus inhabiting pig premises in Portugal. J. Gen. Virol. 85 (8), 2177 - 2187, doi:10.1099/vir.0.80058-0.

Boinas, F.S., Wilson, A.J., Hutchings, G.H., Martins, C., Dixon, L.J., 2011. The persistence of African swine fever virus in field-infected Ornithodoros erraticus during the ASF endemic period in Portugal. PloS one 6(5), e20383, doi:10.1371/journal.pone.0020383.

Boshoff, C.I., Bastos, A.D.S., Gerber, L.J., Vosloo, W., 2007. Genetic characterisation of African swine fever viruses from outbreaks in southern Africa (1973 - 1999), Vet. Microbiol. 121 (1/2), 45 - 55, doi:10.1016/j.vetmic.2006.11.007.

Bosma, R.H., Zongo, L.C., Sané, A., Zoungrana, C., Soudré, A., 2004. Comparaison participatoire de trois méthodes 
d'engraissement des porcs dans les provinces du Sanguié et du Boulkiemdé au Burkina Faso. Livest. Res. Rur. Dev. 16 (2), http://www.lrrd.org/lrrd16/2/bosm1602.htm (accessed 30 April 2012).

Câmara, N.J. Gago da, 1933. História da peste suína em Angola. Pecuária, An. Serv. pecuários da Colónia de Angola 1932 (1), 25 - 40.

Catley, A., Leyland, T., Mariner,J.C., Akabwai, D.M.O., Admassu, B., Asfaw, W., Bekele, G., Hassan H, Sh., 2004. Para-veterinary professionals and the development of quality, self-sustaining community-based services. Rev. sci. tech. Off. int. Epiz. 23 (1), 225 - 252.

Chabo, R.G., Malope, P., Babusi, B., 2000. Pig productivity: A case study for south-eastern Botswana. Livest. Res. Rur. Dev. 12 (3), http://www.lrrd.org/lrrd12/3/cha123.htm. Accessed 30 April 2012.

Chiduwa, G., Chimonyo, M., Halimani, T.E., Chisambara, S.R., Dzama, K., 2008. Herd dynamics and contribution of indigenous pigs to the livelihoods of rural farmers in a semi-arid area of Zimbabwe. Trop. Anim. Health Prod. 40 (2), 125 - 136, doi:10.1007/s11250-007-9071-8.

Chimonyo, M., Dzama, K., Mapiye, C., 2010. Growth performance and carcass characteristics of indigenous Mukota pigs of Zimbabwe. Tropical Animal Health and Production 42 (5), 1001 - 1007 , doi:10.1007/s11250-009-9522-5.

Codjo, A.B., 2003. Estimation des besoins énergétiques du porc local du Bénin entre 7 et $22 \mathrm{~kg}$ de poids vif. Tropicultura $21(2), 56-60$.

Connor, R.J., Van den Bossche, P., 2004. African animal trypanosomoses, in J.A. Coetzer and R.C. Tustin (eds) Infectious diseases of livestock ( $2^{\text {nd }}$ edn) Volume 1, pp. 251 - 296, Oxford University Press, Cape Town.

Costard, S., Porphyre, V., Messad, S., Rakotondrahanta,S., Vidon, H.,Roger, F., Pfeiffer, D.U., 2009a. Multivariate analysis of management and biosecurity practices in smallholder pig farms in Madagascar. Prev. Vet. Med. 92 (3), 199 - 209, doi:10.1016/j.preventmed.2009.08.010.

Costard, S., Wieland, B., de Glanville, W., Jori, F., Rowlands, R., Vosloo, W., Roger, F., Pfeiffer, D.U., Dixon, L.K., 2009b. African swine fever: How can global spread be prevented? Phil. Trans. R. Soc. B 364 (1530), 2683 - 2696, doi:10.1098/rstb.2009.0098.

Darfour-Oduro, K.A., Naazie, A., Ahunu, B.K., Aboagye, G.S., 2009. Genetic parameter estimates of growth traits of indigenous pigs in Northern Ghana. Livest. Sci. 125 (2/3), 187 - 191, doi:10.1016/j.livsci.2009.04.007.

Davies, G., 1994. Eradication of epidemic pig diseases in the European Union. Vet. Rec. 135 (24): 567 - 568. 
De Kock, G., Robinson, E.M., Keppel, J.J.G., 1940. Swine fever in South Africa. Onderstepoort J. Vet. Sci. Anim. Ind. $14(1 / 2), 31-93$.

Ekue, N.F. and Wilkinson, P.J., 1990. Absence of Ornithodoros moubata, the vector of African swine fever virus, from the main pig producing area of Cameroon. Trop. Anim. Health Prod. 22 (2), 127 - 131, doi:10.1007/BF02239840.

El Hicheri, K., Gomez-Tejedor, C., Penrith, M.-L., Davies, G., Douati, A., Edoukou, G. and Wojciechowski, K., 1998. L'épizootie de peste porcine africaine de 1996 en Côte d'Ivoire. Rev. sci. tech., Off. Int. Epiz. 17 (3) $660-673$.

Ellis, J.,Galvin, K.A., 1994. Climate patterns and land use practices in the dry zones of Africa. Bioscience 44 (5), 340-349.

Etter, E.M.C., Seck, I., Grosbois, V., Jori, F., Blanco, E., Vial, L., Akakpo, A.J., Bada-Alhambedji, R., Kone, P. and Roger, F.L., 2011. Seroprevalence of African swine fever in Senegal, 2006. Emerg. Infect. Dis. 17 (1), 49 - 54.

FAO, 2011. A value chain approach to animal diseases risk management - Technical foundations and practical framework for application. Animal Production and Health Guidelines, No. 4, Rome.

FAO, 2012a. Secteur porcin Burkina Faso. Revues nationales de l'élevage de la division de la production et de la santé animales de la FAO. No. 1. Rome.

FAO, 2012b. Secteur porcin Republique Democratique du Congo. Revues nationales de l'élevage de la division de la production et de la santé animales de la FAO. No. 2. Rome.

FAO, 2012c. Pig sector Kenya. FAO Animal Production and Health Livestock Country Reviews. No 3. Rome.

FAOSTAT, 2011.http://faostat.fao.org/site/339/default.aspx.

Fasina, F.O., Agbaje, M., Ajani, F.L., Talabi, O.A., Lazarus, D.D., Gallardo, C., Thompson, P.N., Bastos, A.D.S., in press. Risk factors for farm-level African swine fever infection in major pig-producing areas in Nigeria, 1997 2011. PREVET (2012), http://dx.doi.org/10.1016/j.prevetmed.2012.05.011 (accessed 11 August 2012).

Fasina, F.O, Lazarus, D.D., Spencer, B.T., Makinde, A.A., Bastos, A.D.S., 2012. Cost implications of African swine fever in smallholder farrow-to-finish units: economic benefits of disease prevention through biosecurity. Transbound. Emerg. Dis. 59 (3), 244 - 255, doi:10.1111/j.1865-1682.2011.01261.x.

Fasina, F.O., Shamaki, D., Makinde, A.A., Lombin, L.H., Lazarus, D.D., Rufai, S.A., Adamu, S.S., Agom, D., Pelayo, V., Soler, A., Simón, A., Adedji, A.A., Yakubu, M.B., Mantip, S., Benshak, A.J., Okeke, I., Anagor, P., Mandeng, 
D.C., Akanbi, B.O., Ajibade, A.A., Faramade, I., Kazeem, M.M., Enurah, L.U., Bishop, R., Anchuelo, R., Martin, J.H. \& Gallardo, C., 2010, Surveillance for African swine fever in Nigeria, 2006 - 2009. Transbound. Emerg. Dis. 57 (4), $244-253$.

Food and Agriculture Organisation of the United Nations/World Organisation for Animal Health/World Bank, 2010. Good practices for biosecurity in the pig sector - issues and options in developing and transition countries. FAO Animal Production and Health Paper No. 169. Rome, FAO.

Foueré, M., 2007. Reportage à Madagascar: un pro du porc.

http://pigtrop.cirad.fr/subjects/animal_husbandry_and_sustainable_practices/reportage_a_madaga scar un pro du porc.pdf (accessed 17 June 2012).

Gallardo C, Anchuelo R, Pelayo V, Poudevigne F, Leon T, Nzoussi J, et al. 2011. African swine fever virus p72 genotype IX in domestic pigs, Congo, 2009. Emerg. Infect. Dis. 17 (8), 1556-8.

Ganaba, R., Praet, N., Carabin, H., Millogo, A., Tarnagda, Z., Dorniy, P., Hounton, S., Sow, A., Nitiéma, P., Cowan, L.D., 2011. Factors associated with the prevalence of circulating antigens to porcine cysticercosis in three villages of Burkina Faso. PLoS Negl. Trop. Dis. 5 (1), e927, doi:10.1371/journal.pntd.0000927.

Garcês, A., Casey, N.H., Otto, F., 1998. Factors limiting pig breeding in Maputo, Mozambique. Isr. J. Vet. Med. $53(1), 21-24$.

Githigia, S.M., Murekefu, K., Otieno, R.O., 2005. Prevalence of porcine cysticercosis and risk of Taenia solium taeniosis in Funyula Division of Busia District, Kenya. J. Kenya Vet. Ass. 29, 37 - 39.

Gonzague, M., Roger, F., Bastos, A., Burger, C., Randriamparany, T., Smondack, S., Cruciere, C., 2001. Isolation of a non-haemadsorbing, non-cytopathic strain of African swine fever virus in Madagascar. Epidem. Infect. 126 (3), $453-459$.

Halimani, T.E., Muchadeyi, F.C., Chimonyo, M., Dzama, K., 2010. Pig genetic resource conservation: the southern African perspective. Ecol. Econ. 69 (5), 944 - 951, doi:10.1016/j.ecolecon.2010.01.005.

Halimani, T.E., Muchadeyi, F.C., Chimonyo, M., Dzama, K., 2012. Opportunities for conservation and utilisation of local pig breeds in low-input production systems in Zimbabwe and South Africa. Trop. Anim. Health Prod. doi:10.1007/s1 1250-012-0177-2.

Halimani, T.E., Ndlovu, L.R., Dzama, K., Chimonyo, M., Miller, B.G., 2007. Growth performance of pigs fed on diets containing Acacia karroo, Acacia nilotica and Colophospermum mopane leaf meals. Livest. Res. Rur. Dev. 19 (12), http://www.lrrd.org/lrrd19/12/hali19187.htm (accessed 17 June 2012). 
Haresnape, J.M., Lungu, S.A.M, Mamu, F.D., 1985. A four-year survey of African swine fever in Malawi. J. Hyg. Cambridge 95 (2), 309 - 322.

Haresnape, J.M., Lungu, S.A.M., Mamu, F.D., 1987. An updated survey of African swine fever in Malawi. Epidemiol. Infect. 99 (3), 723 - 732.

Haresnape, J., Mamu, F.D., 1986. The distribution of ticks of the Ornithodoros moubata complex (Ixodoidea: Argasidae) in Malawi, and its relation to African swine fever epizootiology. J. Hyg. Cambridge 96 (3), $535-544$.

Haresnape, J.M., Wilkinson, P.J., Mellor, P.S., 1988. Isolation of African swine fever virus from ticks of the Ornithodoros moubata complex (Ixodoidea: Argasidae) collected within the African swine fever enzootic area of Malawi. Epidemiol. Infect. 101 (1), 173 - 185.

Haresnape, J.M., Wilkinson, P.J., 1989. A study of African swine fever infected ticks (Ornithodoros moubata) collected from three villages in the ASF enzootic area of Malawi following an outbreak of the disease in domestic pigs. Epidemiol. Infect. 102 (3), 507 - 522.

Huttner, K., Leidl, K., Jere, F.B.D., Pfeiffer, D.U., 2000. Characteristics and performance of village animal health workers and veterinary assistants in northern Malawi. J. S. Afr. Vet. Ass. 71 (3), 160 - 165.

Ironkwe, M.O., Amefule, K.U., 2008. Appraisal of indigenous pig production and management practices in Rivers State, Nigeria. J. Agr. Soc. Res. 8, 1 - 7.

Jahnke, H.E., 1982. Livestock production systems and livestock development in tropical Africa. Kieler Wissenschaftsverlag Vauk, Kiel.

Jori, F., Bastos, A.D.S., 2009. Role of wild suids in the epidemiology of African swine fever. EcoHealth 6 (2), 296-310, doi:10.1007/s10393-009-0248-7.

Jori, F., Vial, L., Penrith, M.L., Perez-Sanchez, R., Etter, E., Albina, E., Michaud, V., Roger, F., this volume. The sylvatic cycle of African swine fever in Sub-saharan Africa and the Indian Ocean. Virus Res.

Kagira, J.M., Maingi, N., Kanyari, P.W.N., Githigia, S.M., Ng'ang'a, J.C., Gachoi, J.M., 2010a. Characteristics of pig trade in low income settings in Busia District, Kenya. Tanzania Vet. J. 27, 27 - 35.

Kagira, J.M., Maingi, N., Kanyari, P.W.N., Githigia, S.M., Ng'ang'a, J.C., Karuga, J.W., 2010b. Characteristics of the smallholder free-range pig production system in western Kenya. Trop. Anim. Health Prod. 42 (5), $865-873$. 
Karimuribo, E.D., Chenyambuga, S.W., Makene, V.W., Mathias, S., 2011. Characteristics and production constraints of rural-based small-scale pig farming in Iringa region, Tanzania. Livest. Res. Rur. Dev. 23 (8), http://www.lrrd.org/lrrd23/8/Kari23172.htm (accessed 30 April 2012).

Koussou, M.O., Duteurtre, G., 2002. Les facteurs de compétitivité de la filière porcine dans le bassin du logone. Communication au colloque 'Systèmes agro-alimentaires localisés', Montpellier, CIRAD, France, 16 - 18 Oct. 2002 ,

http://pigtrop.cirad.fr/subjects/socio_economy_in_pig_production_sector/filiere_porcin_au_nord_c ameroun (accessed 17 June 2012).

Lage, M.C.D. and Oliveira da Silva, R.D.C., 1980. Peste suína africana em S. Tomé ePrincipe. Rep. Trab. Inst. Nac. Vet. 12, $23-28$.

Lekule, F.P., Kyvsgaard, N.C., 2003. Improving pig husbandry in tropical resource-poor communities and its potential to reduce risk of porcine cysticercosis. Acta Trop. 87 (1), $111-117$.

Lubisi, B.A., Bastos, A.D.S., Dwarka, R.M., Vosloo, W., 2005. Molecular epidemiology of African swine fever in East Africa. Arch. Virol. 150 (12), 2439 - 2452, doi:10.1007/s00705-005-0602-1.

Lubisi, B.A., Dwarka, R.M., Meenowa, D., Jaumally, R., 2009. An investigation into the first outbreak of African swine fever in the Republic of Mauritius. Transbound. Emerg. Dis. 56 (5), 178 - 188, doi:10.1111/j.1865-1682.2009.01078.x.

Luther, N.J., Majiyagbe, K.A., Shamaki, D., Lombin, L.H., Antiabong, J.F., Bitrus, Y., Owolodun, O., 2007a. Detection of African swine fever virus genomic DNA in a Nigerian red river hog (Potamochoerus porcus). Vet. Rec. 160 (2), 58 - 59.

Luther, N.J., Udeama, P.G., Majiyagbe, K.A., Shamaki, D., Antiabong, J.F., Bitrus, Y., Nwosuh, C.I., Owolodun, O., 2007b. Polymerase chain reaction (PCR) detection of the genome of African swine fever virus (ASFV) from natural infection in a Nigerian baby warthog (Phacochoerus aethiopicus). Nigerian Vet. J. 28 (2), $63-67$.

Lyra, T.M.P., 2006. La erradicación de la peste porcina africana en el Brasil, 1978 - 1984. Rev. sci. tech. Off. int. Epiz. 25 (1), 93 - 103.

Madzimure, J., Chimnonyo, M., Zander, K.K., Dzama, K., 2012. Potential for using indigenous pigs in subsistence-oriented and market-oriented small scale farming systems of southern Africa. Trop. Anim. Health Prod. doi:10.1007/sl 1250-012-0184-3. 
Mashatise, E., Hamudikuwanda, H., Dzama, K., Chimonyo, M., Kanengoni, A., 2005. Socio-economic roles, traditional management systems and reproductive patterns of mukota pigs in semi-arid northeastern Zimbabwe. Bunda J. Agr. Env. Sci. Technol. 3 (1), 97 - 105.

Matos, C., Sitoe, C., Afónso, S., Banze, J., Baptista, J., Dias, G., Rodrigues, F., Atanásio, A., Nhamusso, A., Penrith, M.-L., Willingham, A.L. III, 2011. A pilot study of common health problems in smallholder pigs in Angónia and Boane districts, Mozambique. J. S. Afr. Vet. Ass. 82 (3), 166 - 169.

Matson, B.A., 1960. An outbreak of African swine fever in Nyasaland. Bull. epiz. Dis. Afr. 8, 305 - 308.

Mendes, A.M, 1971. Algumas doenças dos animais em Angola e Moçambique e sua importância na higiene das carnes. Rev. Port. Cienc. Veter. 66 (420), 271 - 286.

Mendes, A.M., 1994. A história da peste suína africana em Angola. Rev. Port. Ciênc. Vet. 89 (511), 110 120.

Michaud, V., Gil, P., Kwiatek, O., Prome, S., Dixon, L., Romero, L., Le Potier, M.F., Arias, M., Couacy-Hymann, E., Roger, F., Libeau, G., Albina, E., 2007. Long-term storage at tropical temperature of dried-blood filter papers for detection and genotyping of RNA and DNA viruses by direct PCR. J. Virol. Methods 146(1-2), 257-265.

Misinzo, G., Magambo, J., Masambu, J., Yongolo, M.G., Van Doorsselaere, J., Nauwynck, H.J., 2010. Genetic characterization of African swine fever viruses from a 2008 outbreak in Tanzania. Transbound. Emerg. Dis. 58 (1), 86 - 92, doi:10.1111/j. 1865-1682-2010-01177.x.

Missohou, A., Niang, M., Foucher, H., Dieye, P.N., 2001. Pig production systems in Lower Casamance, (Senegal). Cah. Agric. 10, 405 - 408.

Montgomery, R.E., 1921. On a form of swine fever occurring in British East Africa (Kenya Colony). J. Comp. Pathol. 34 (3/4), 159 - 191, 243 - 262.

Mopate Logtene, Y., Kabore-Zoungrana, C.-Y., 2010. Dynamique des élevages et caractéristiques des producteurs de porcs de la ville de N'Djaména, Tchad, in: Seiny-Boukar, L., Boumard, P. (Eds.), Actes du colloque 'Savanes áfricaines en développement: innover pour durer', 20 - 23 April 2009, Garoua, Cameroon. Prasac, N'Djamena, Chad; CIRAD, Montpellier.

Mopate Logtene, Y., Koussou, M.O., 2003. L'élevage porcin, un élevage ignoré mais poutant implanté dans les agro-systèmes ruraux et périurbains du Tchad, in: Jamin, J.Y., Seiny Boukar, L., Floret, C. (Eds.), Savanes africaines: des espaces en mutation, des acteurs face à de nouveaux défis. Actes du colloque, mai 2002, Garoua, Cameroun. Prasac, N'Djamena, Tchad. CIRAD, Montpellier. 


\section{http://pigtrop.cirad.fr/subjects/socio_economy_in}

_pig_production_sector/periurban_and_rural_pig_sector_in_chad (accessed 27 May 2012).

Moreki, J.C., Mphinyane, H.G., 2011. Opportunities and challenges of pig production in Botswana. Livest. Res. Rur. Dev. 23 (4),http://www.lrrd.org/lrrd23/4/more23087.htm (accessed 30 April 2012).

Moura, J.A., McManus, C.M., Bernal. F.E.M., de Melo, C.B., 2010. An analysis of the 1978 outbreak of African swine fever in Brazil and its eradication. Rev. sci. tech. Off. int. Epiz. 29 (3), 549 - 563.

Muhanguzi, D., Lutwama, V., Mwiine, F.N., 2012. Factors that influence pig production in Central Uganda case study of Nangabo Sub-County, Wakiso district. Vet. World 5 (6), 346 - 351, doi:10.5455/vetworld.2012.346-351.

Mutua, F.K., Dewey, C.E., Arimi, S.M., Ogara, W.O., Githigia, S.M., Levy, M., Schelling, E., 2011. Indigenous pig management practices in rural villages of Western Kenya. Livest. Res. Rur. Dev. 23 (7), http://www.lrrd.org/lrrd23/7/mutu23144.htm (accessed 17 June 2012).

Nana-Nukechap, M.F., Gibbs, E.P.J., 1985. Socioeconomic effects of African swine fever in Cameroon. Trop. Anim. Health Prod. 17 (3), 183 - 184.

Ncube, M., Dzama, K., Chimonyo, M., Kanengoni, a., Hamudikwanda, H., 2003. Effect of boar genotype on reproductive performance of the local sows of Zimbabwe. Livest. Res. Rur. Dev. 15 (2), http://www.lrrd.org/lrrd15/2/ncub152.htm (accessed 30 April 2012).

Ndébi, G., Kamajou, J., Ongla, J., 2009. Analyse des contraintes au développement de la production porcine au Cameroun. Tropicultura 27 (2), $70-76$.

Ndébi, G., Kamgnia, B.D., Tchoumboué, J., 2004. Etude des marges dans les circuits de commercialisation du porc au Cameroun. Tropicultura 22 (3), 104 - 109.

Ndébi, G., Ongla, J., 2006. Fonctionnement des systèmes de distribution du porc au Cameroun. Tropicultura 24 (2), $73-81$.

Ngowi, H.A.,, Mlangwa, J.E.D., Carabin, H., Mlozi, M.R.S., Kassuku, A.A., Kimera, S.I., Willingham III, A.L., 2007. Financial efficiency of health and pig management education intervention in controlling porcine cysticercosis in Mbulu District, northern Tanzania. Livest. Res. Rur. Dev. 19 Article\#62 http://www.lrrd.org/lrrd19/5/ngowi19062.htm (accessed 26 May 2012).

Nissen, S., Poulsen, I.H., Nejsum, P., Olsen, A., Roepstorff, A., Rubaire-Akiiki, C., Thamsborg, S.M., 2011. Prevalence of gastrointestinal nematodes in growing pigs in Kabale District in Uganda. Trop. Anim. Health 
Prod. 43 (3), 567 - 572, doi:10.1007/s11250-010-9732-x.

Nix, R.J., Gallardo, C., Hutchings, G., Blanco, E., Dixon, L.K., 2006. Molecular epidemiology of African swine fever virus studied by analysis of four variable genome regions. Arch. Virol. 151 (12), 2475 - 2494, doi:10.1007/s00705-006-0654-2.

Nsoso, S.J., Mannathoko, G.G., Modise, K. 2006. Monitoring production, health and marketing of indigenous Tswana pigs in Ramotswa village of Botswana. Livest. Res. Rur. Dev. 18 (9) http://www.lrrd.org/lrrd18/9/nsos18125.htm (accessed 30 April 2012).

Nwanta, J.A., Shoyinka, S.V.O., Chah, K.F., Onunkwo, J.I., Onyenwe, I.W., Eze, J.I., Iheagwam, C.N., Njoga, E.M., Onyema, I., Ogbu, K.I., Mbegbu, E.C., Nnadozie, P.N., Ibe, E.C., Oladimeji, K.T., 2011. Production characteristics, disease prevalence, and herd-health management of pigs in Southeast Nigeria. J. Swine Health Prod. 19 (6), 331 - 339.

Ogunniyi, L.T., Ajao, A.O., 2011. Investigation of factors influencing the technical efficiencies of swine farmers in Nigeria. J. Hum. Ecol. 35 (3), 203 - 208.

OIE, 2009. Event summary: African swine fever, Mauritius.

http://www.oie.int/wahis/public.php?page=event_summary\&this_country_code=MUS\&reportid=63 69 (accessed 19 August 2012).

OIE, 2012a. Terrestrial animal health code.

http://www.oie.int/international-standard-setting/terrestrial-code/access-online/ (accessed 3

October 2012).

OIE, 2012b. Handistatus II. http://www.oie.int/hs2/report.asp?lang=en.

OIE, 2012c. WAHID Interface, http://www.oie.int/wahis/public.php?page=home.

Oliver, W.L.R., Brisbin, L., 1993. Introduced and feral pigs: problems, policy and priorities, in Oliver, W.L.R. (ed.), Pigs, peccaries and hippos: status survey and conservation action plan, pp. 269 - 286. Gland, IUCN.

Olugasa, B.O., Ijagbone, I.F., 2007. Pattern of spread of African swine fever in south-western Nigeria, 1997 2005. Vet. ital. 43 (3), $621-628$.

Olugasa, B.O., Ayoade, G.O., Adu, F.D., Adeola, O.A., 2009a. Prevalence of African swine fever virus antibodies in pig herds in Southwest Nigeria, in Sustainable animal husbandry: prevention is better than cure. Volume 1. Proceedings of the $14^{\text {th }}$ International Congress of the International Society for Animal Hygiene (ISAH), Vechta, Germany, 19-23 July 2009, pp. 105- 108. 
Olugasa, B.O., Soetan, K.O., Omotade, O.O., Agbede, S.A., 2009b. African swine fever biocontainment adoption in Ibadan, Nigeria: problems, needs and opportunities, in Sustainable animal husbandry: prevention is better than cure. Volume 2. Proceedings of the $14^{\text {th }}$ International Congress of the International Society for Animal Hygiene (ISAH), Vechta, Germany, 19-23 July 2009, pp. 947 - 950.

Onyenweaku, C.E., Effiong, E.O., 2005. Technical efficiency in pig production in Akwa Ibom State, Nigeria. Int. J. Agr. Rur. Dev. 6, $51-57$.

Owolodun, O.A., Obishakin, E.T., Ekong, P.S., Yakubu, B., 2010a. Investigation of African swine fever in slaughtered pigs, Plateau State, Nigeria, 2004 - 2006. Trop. Anim. Health Prod. 42 (8), 1605 - 1610, doi:10.1007/s11250-010-9635-x.

Owolodun, O.A., Yakubu, B., Antiabong, J.F., Ogedengbe, O.E., Luka, P.D., John Audu, B., Ekong, P.S., Shamaki, D., 2010b. Spatio-temporal dynamics of African swine fever outbreaks in Nigeria, 2002 - 2007. Transbound. Emerg. Dis. 57 (5), 330 - 339.

Penrith, M.-L., 2008. Mission report on the consultancy to establish progress in the control of ASF outbreak in Mauritius and to develop a TCP in view of long term strategy for control and repopulation. TCP/MAR/3101, Food and Agriculture Organization of United Nations, Rome.

Penrith, M.-L., Lopes Pereira, C., Lopes da Silva, M.M.R., Quembo, C., Nhamusso, A., Banze, J., 2007. African swine fever in Mozambique: review, risk factors and considerations for control. Onderstepoort J. Vet. Res. 74 (2), $149-160$.

Penrith, M.-L., Thomson, G.R., 2004. Special factors affecting the control of livestock diseases in sub-Saharan Africa, in J.A. Coetzer and R.C. Tustin (eds) Infectious Diseases of Livestock (2 ${ }^{\text {nd }}$ edn) Volume 1, pp. 171 - 177 , Oxford University Press, Cape Town.

Penrith, M.-L., Thomson, G.R. and Bastos, A.D.S., 2004a. African swine fever, in J.A. Coetzer and R.C. Tustin (eds) Infectious Diseases of Livestock ( $2^{\text {nd }}$ edn) Volume 2, pp. 1087 - 1119, Oxford University Press, Cape Town.

Penrith, M.-L., Thomson, G.R., Bastos, A.D.S., Phiri, O.C., Lubisi, B.A., Du Plessis, E.C., Macome, F., Pinto, F., Botha, B., Esterhuysen, J., 2004b. An investigation into natural resistance to African swine fever in domestic pigs from an endemic area in southern Africa. Rev. sci. tech., Off. int. Epiz. 23 (3), 965 - 977.

Penrith, M.-L., Vosloo, W., 2009. Review of African swine fever: transmission, spread and control. J. S. Afr. Vet. Ass. 80 (2), $58-62$.

Penrith, M.-L., Vosloo, W., Mather, C., 2011. Classical swine fever (hog cholera): review of aspects relevant to 
control. Transbound. Emerg. Dis. 58 (3), 187 - 196, doi:10.1111/j.1865-1682.2011.01205.x.

Pérez-Sánchez, R., Astigarraga, A., Oleaga-Pérez, A., Encinas-Grandes, A., 1994. Relationship between the persistence of African swine fever and the distribution of Ornithodoros erraticus in the province of Salamanca, Spain. Vet. Rec. 135 (9), 207 -209, doi:10.1136/vr.135.9.207.

Perry, B.D. and Grace, D., 2009. The impacts of livestock diseases and their control on growth and development processes that are pro-poor. Phil. Trans. R. Soc. B 364 (1530), 2643 - 2655, doi: 10.1098/rstb.2009.0097.

Perry, B.D., Grace, D., Sones, K., 2011. Current drivers and future directions of global livestock disease dynamics. PNAS Early Edition, http://www.pnas.org/cgi/doi/10.1073/pnas1012953108 (accessed 21 May 2011).

Perry, B.D., Sones, K.R., 2008. Strengthening demand-led animal health services in pastoral areas of the IGAD region. IGAD LPI Working Paper No. 09-08, FAO, Rome.

Perry, B.D., Randolph, T.F., McDermott, J.J., Sones, K.R., Thornton, P.K., 2002. Investing in animal health research to alleviate poverty. ILRI, Nairobi.

Peters, D., 2008. Assessment of the potential of sweetpotato as livestock feed in East Africa: Rwanda, Uganda and Kenya. A report presented to the International Potato Center (CIP), Nairobi.

http://www.fao.org/fileadmin/templates/agphome/images/iclsd/documents/wk1 c13 claessens.pd f (accessed 29 July 2012).

Petrus, N.P., Mpofu, I., Schneider, M.B., Nepembe, M., 2011. The constraints and potentials of pig production among communal farmers in Etayi Constituency of Namibia. Livest. Res. Rur. Dev. 23 (7) http://www.Irrd.org/lrrd23/7/petr23159.htm (accessed 30 April 2012).

Phiri, I.K., Ngowi, H., Afonso, S., Matenga, E., Boa, M., Mukaratirwa, S., Githigia, S., Saimo, M., Sikasinge, C., Maingi, N., Lubega, G.W., Kassuku, A., Michael, L., Siziya, S., Krecek, R.C., Noormahomed, E., Vilhena, M., Dorny, P., Willingham, A.L. III., 2003. The emergence of Taenia solium cysticercosis as a serious agricultural problem and human health risk. Acta Trop. 87 (1), 13 - 23.

Plowright, W., Parker, J.A. and Pierce, M.A., 1969. African swine fever virus in ticks (Ornithodoros moubata Murray) collected from animal burrows in Tanzania. Nature 221 (5185), 1071 - 1073, doi:10.1038/2211071a0.

Plowright, W., Thomson, G.R. and Neser, J.A., 1994. African swine fever, in J.A. Coetzer, G.R. Thomson and R,C, Tustin (eds) Infectious Diseases of Livestock, with special reference to southern Africa Volume 1, pp. 
568 - 599, Oxford University Press, Cape Town.

Pondja, A., Neves, L., Mlangwa, J., Afonso, S., Fafetine, J., Willingham, A.L. III, Thamsborg, S.M., Johansen, M.V., 2010. Prevalence and risk factors of porcine cysticercosis in Angónia District, northern Mozambique. PLoS Negl. Trop. Dis. 4 (2), e594, doi:10.1371/journal.pntd.0000594.

Psilos, P., 2007. Smallholder swine-pig meat production in Asia. A conceptual framework for competitiveness: using analysis from the Lower Mekong region. Strengthening the contribution of livestock to economic growth in Asia. http://aphca.org/dmdocuments/APHCA

Publications/swine framework concept paper fin.pdf (accessed 1 July 2012).

Pujols-Romeu, J., Badiola-Saiz, J.I., Pérez de Rozas, J.M., Rosell-Bellsola, R., Carreras-Mauri, J., 1991a. Papel que tienen los cerdos portadores en el mantenimiento e transmisión del virus de la PPA. I. Estudo epizootiológico. Med. vet. 8 (9), 481 - 486, $488-489$.

Pujols-Romeu, J., Badiola-Saiz, J.I., Pérez de Rozas, J.M., Segura-Cardona, L., Saco-Galvany, M., 1991b. Papel que tienen los cerdos portadores en el mantenimiento e transmisión del virus de la PPA. II. Aislamiento del virus de animales seropositivos. Med. vet. 8 (10), 560 - 566.

Roger, F., Ratovonjato, J., Vola, P., Uilenberg, G., 2001. Ornithodoros porcinus ticks, bushpigs, and African swine fever in Madagascar. Exp. Appl. Acarol. 25 (3), 263 - 269, doi:10.1023/A:1010687502145.

Rolesu, S., Aloi, D., Ghironi, A., Oggiano, N., Oggiano, A., Puggioni, G., Patta, C., Farina,, S., Montinaro, S., 2007. Geographical information systems: a useful tool to approach African swine fever surveillance management of wild pig populations. Vet. ital. 43 (3), $463-467$.

Sánchez Botija, A.C., 1963. Reservórios del virus de la peste porcina africana. Investigación del virus de la P.P.A. en los artrópodos mediante la prueba de la hemadsorción. Bull. Off. Int. Epiz. 60, 895 - 899.

Sánchez-Vizcaíno, J.M., Mur, L., Martínez-López, B., 2012. African swine fever: an epidemiological update. Transbound. Emerg. Dis. 59 (suppl. 1), 27 - 35, doi: 10.1111/j.1865-1682.2011.01293.x.

Scott, G.R., 1965. Prevention, control and eradication of African swine fever. Bull. Off. int. Épiz. 63 (5/6), $751-764$.

Sikasunge, C., Phiri, I.K., Phiri, A.M., Dorny, P., Siziya, S., Willingham, A.L. III, 2007. Risk factors associated with porcine cysticercosis in selected districts of Eastern and Southern provinces of Zambia. Vet. Parasitol. 143 (1), 59 - 66, doi:10.1016/j.vetpar.2006.07.023.

Steyn, D.G., 1928. Preliminary report on a South African virus disease amongst pigs. $13^{\text {th }}$ and $14^{\text {th }}$ Reports of the 
Director of Veterinary Education and Research, Union of South Africa, pp. 415 - 428.

Steyn, D.G., 1932. East African virus disease in pigs. $18^{\text {th }}$ Report of the Director of Veterinary Services and Animal Industry, Union of South Africa 1, pp. 99 - 109.

Sutherst, R.W., 2001. The vulnerability of animal and human health to parasites under global change. Int. J. Parasitol. 31 (9), 933-948, doi:10.1016/S0020-7519(01)00203-X.

Taylor, W.P., Best, J.R., Couquhoun, I.R., 1977. Absence of African swine fever from Nigerian warthogs. Bull. Anim. Health Prod. Afr. 25 (2), 196 - 197.

Thomson, G.R., 1985. The epidemiology of African swine fever: the role of free living hosts in Africa. Onderstepoort J. Vet. Res. 52 (3), 201-209.

Thomson, G.R., Tambi, E.N., Hargreaves, S.K., Leyland, T.J., Catley, A.P., van 't Klooster, G.G.M. \& Penrith, M-L., 2004. International trade in livestock and livestock products: The need for a commodity-based approach. Vet. Rec. 155 (14), 429-433.

Valadão, F.G., 1969. Notas sobre alguns estudos realizados em porcos sobreviventes de peste suína africana. An. Serv. Vet. Moçamb. 12/14, 1964 - 1966 (1969), 95 - 100.

Veary, C.M., Manoto, S.M., 2008. Neurocysticercosis: a possible cause of epileptiform seizures in people residing in villages served by the Bethanie clinic in the North West province of South Africa. J. S. Afr. Vet. Ass. 79 (2), $84-88$.

Verhulst, A., 1993. Lessons from field experiences in the development of monogastric animal production in: Mack, S. (Ed.), Strategies for sustainable animal agriculture in developing countries.

Proceedings of the FAO Expert Consultation held in Rome, Italy, 10 - 14 December 1990. FAO Animal Health and Production Paper 107, pp. 261 - 271. http://www.fao.org/DOCREP/004/T0582E/T0582E27.htm (accessed 28 May 2012).

Vial, L., Diatta, G., Tali, A., Ba, E.H., Bouganali, H., Durand, P., Sokhna, C., Rogier, C., Renaud, F., Trape, J.-F., 2006. Incidence of tick-borne relapsing fever in West Africa: longitudinal study. Lancet 368 (9529), 37 43.

Vial, L., Wieland, B., Jori, F., Etter, E., Dixon, L., Roger, F., 2007. African swine fever virus in soft ticks, Senegal. Emerg. Infect. Dis. 13 (12), 1928 - 1931.

Wabacha, J.K., Maribei, J.M., Mulei, C.M., Kyule, M.N., Zessin, K.H., Oluoch-Kosura, W., 2004. 
Characterisation of smallholder pig production in Kikuyu Division, Central Kenya. Prev. Vet. Med. 63 (3/4), 183 - 195, doi:10.1016/0167-5877(04)00071-6.

Wambura, P.N., Masambu, J. and Msami, H., 2006. Molecular diagnosis and epidemiology of African swine fever outbreaks in Tanzania. Vet. Res. Commun. 30 (6), 667 - 672, doi:10.1007/s11259-006-3280-x.

Wesley, R.D. and Tuthill, A.E., 1984. Genome relatedness among African swine fever virus field isolates by restriction endonuclease analysis. Prev. Vet. Med. 2, 53 - 62, doi:10.1016/0167-5877(84)90048-5.

Wieland, B., Dhollander, S., Salman, M., Koenen, F., 2011. Qualitative risk assessment in a data-scarce environment: A model to assess the impact of control measures on spread of African swine fever. Prev. Vet. Med. 99 (1), 4 - 14, doi:10.1016/j.prevetmed.2011.01.001

Wilkinson, P.J., 1984. The persistence of African swine fever in Africa and the Mediterranean. Prev. Vet. Med., 71 - 82, doi:10.1016/0167-5877(84)90050-3.

Wilkinson, P.J., 1989. African swine fever virus, in M.C. Pensaert (ed.) Virus Infections of Porcines, pp. 17 32, Elsevier, Amsterdam.

Wilkinson, P.J., Wardley, R.C., Williams, S.M., 1983. Studies in pigs infected with African swine fever virus (Malta/78), in Wilkinson, P.J., (ed.). African swine fever. EUR. 8466 EN. Commission of the European Communities.

Youssao, A.K.I., Koutinhouin, G.B., Kpodekon, T.M., Bonou, A.G., Ajakpa, A., Dotcho, C.D.G., Atodjinou, F.J.R., 2008, Production porcine et ressources génétiques locales en zone périurbaine de Cotonou et d'Abomey-Calavi au Bénin. Rev. Élev. Méd. Vét. Pays trop. 61 (3/4), 235 - 243. 


\section{Legends to figures}

Fig. 1. Distribution of African swine fever in Africa.

Fig. 2. a. Number of countries reporting ASF from pre 1949 to 2011. W Africa = West Africa, E/S /C Africa = Eastern, Southern and Central Africa. Sources: Plowright et al., 1994; OIE Bulletins (1975 -1995), OIE Handistatus II (1996 - 2004), OIE WAHID 2005 - 2011. b. Total pig population; for 2010 the countries formerly in USSR and now independent have been allocated to Europe or Asia. Source: FAOSTAT 2010 statistics. c. Pork production for 2010 (1980 figures not given owing to a clear anomaly in the statistics for the former USSR). Source: FAOSTAT 2010 commodity statistics. d. Pig numbers (total) in relation to number of countries reporting African swine fever (ASF) over time. NA = North Africa, WA = West Africa, E/S/C A = East, Southern and Central Africa. Sources: FAOSTAT 2010; Plowright et al., 1994; OIE Bulletins (1980 - 1995), OIE Handistatus II (1996 2004), OIE WAHID 2005 - 2011. Key: NA = North Africa; WA = West Africa; ESA = Eastern and southern Africa. e. Pig numbers in relation to number of countries reporting ASF. Sources: FAOSTAT 2010 and OIE WAHID 2009-2011.

Fig. 3. Pig numbers in African countries in 2010 according to FAOSTAT 2011. The unshaded countries as well as the Comoros Islands reported having no pigs.

Fig. 4. a. Free-ranging village pig, Tohoun,Togo. b. Free-ranging pigs scavenging on garbage, Chicualacuala, Mozambique. c. Semi-intensively kept pigs, Kpalimé, Togo. d. Backyard pig farm, Mauritius.

Fig. 5. a. Modern intensive pig farm, Western Cape Province, South Africa. b. Local breed pigs in a rustic pen, Tohoun, Togo. c. Pig shelter offering habitats for Ornithodoros, Gorongosa, Mozambique. d. Rustic pigsty with wooden walls and earth floor, Madagascar.

Fig. 6. a. Live pig market, Vogan, Togo. b. Open air butchery, Vogan, Togo. c. Unhygienic effluent disposal at an abattoir, Madagascar. d. Warthogs are attracted to areas where human activity may provide food and water.

Fig. 7. a. Farmers receiving training in recognising signs of disease in their pigs, Angónia, 
Mozambique. b. Veterinarians providing on-farm training in pig health care, Mozambique= 
Table 1. Examples of hazards and hazard mitigation for African swine fever along the value chain

\begin{tabular}{|c|c|c|}
\hline Value chain point & Hazard & Mitigation \\
\hline Farm gate/pig facility & $\begin{array}{l}\text { Introduction of ASFV via live } \\
\text { infected pigs or infected material }\end{array}$ & $\begin{array}{l}\text { Closed herd or introduce pigs only } \\
\text { from known healthy sources; } \\
\text { restricted access with compulsory } \\
\text { change of footwear; cleaning and } \\
\text { disinfection to prevent fomites; no } \\
\text { feeding of dangerous food wastes }\end{array}$ \\
\hline Sale of pigs & Asymptomatic infected pigs sold & $\begin{array}{l}\text { Producers understand the danger of } \\
\text { selling pigs during an outbreak in } \\
\text { the herd or in the period } \\
\text { immediately following an outbreak } \\
\text { and maintain quarantine of the } \\
\text { herd }\end{array}$ \\
\hline $\begin{array}{l}\text { Sale of live pigs: transfer } \\
\text { to point of sale }\end{array}$ & $\begin{array}{l}\text { Purchase by traders collecting } \\
\text { and mixing pigs from multiple } \\
\text { farms during transport and/or at } \\
\text { point of sale }\end{array}$ & $\begin{array}{l}\text { Direct sale to buyer when possible; } \\
\text { formalisation of trading of live pigs } \\
\text { to ensure safety of process e.g. } \\
\text { through veterinary inspection }\end{array}$ \\
\hline $\begin{array}{l}\text { Transfer to point of } \\
\text { slaughter }\end{array}$ & $\begin{array}{l}\text { Mixing of pigs from different } \\
\text { herds; holding of mixed pigs at } \\
\text { interim facilities or salesyards; } \\
\text { vehicle contaminated with } \\
\text { infected material }\end{array}$ & $\begin{array}{l}\text { Direct transport from farm to point } \\
\text { of slaughter by producer or by a } \\
\text { reliable agent }\end{array}$ \\
\hline Point of slaughter & $\begin{array}{l}\text { Clinically sick or moribund pigs } \\
\text { entering the food chain and } \\
\text { becoming a source of infected } \\
\text { pork }\end{array}$ & $\begin{array}{l}\text { Ante- and post mortem inspection } \\
\text { carried out by trained meat } \\
\text { inspectors }\end{array}$ \\
\hline Point of slaughter & $\begin{array}{l}\text { Inappropriate disposal of } \\
\text { carcasses of pigs that showed } \\
\text { signs of ASF before or at } \\
\text { slaughter }\end{array}$ & $\begin{array}{l}\text { Training of responsible persons and } \\
\text { proper facilities for safe disposal of } \\
\text { abattoir waste material }\end{array}$ \\
\hline
\end{tabular}




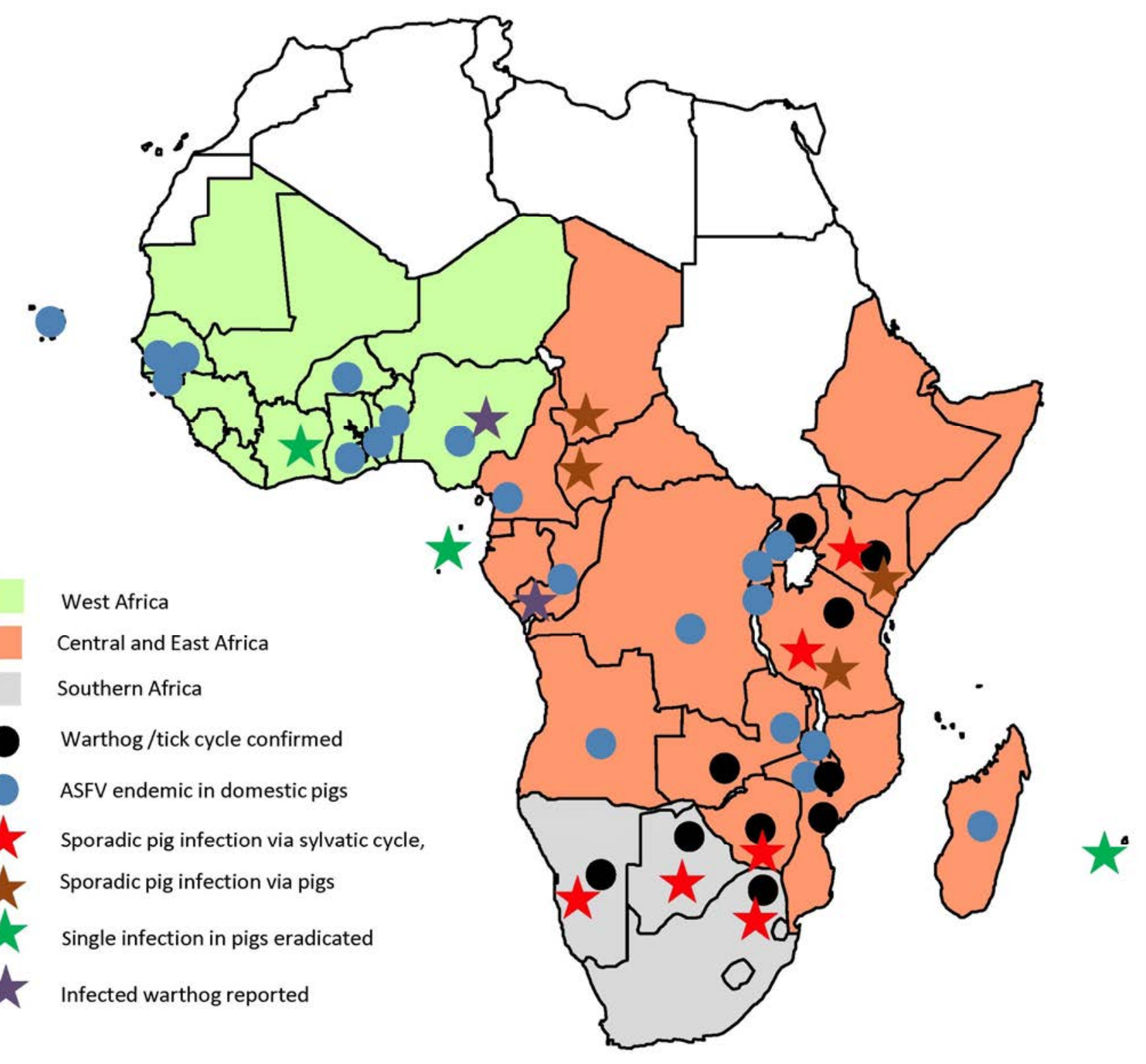




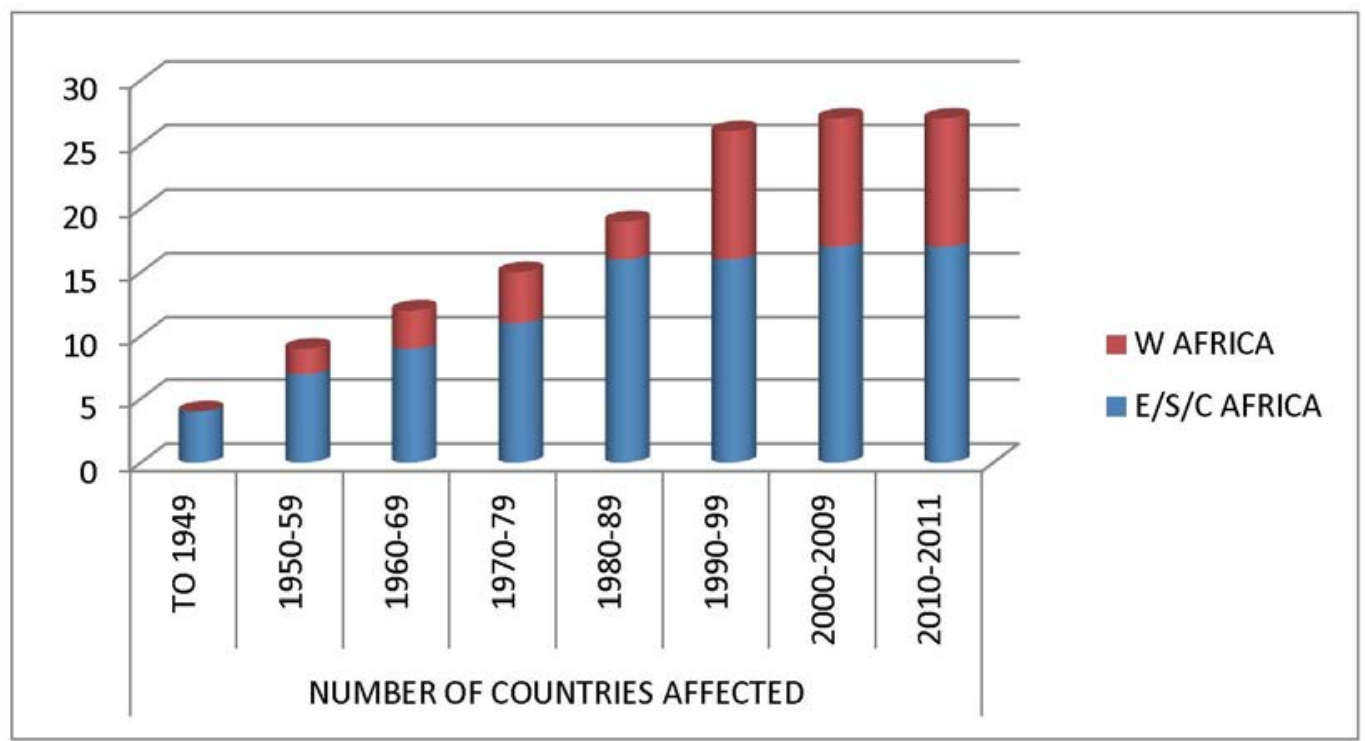




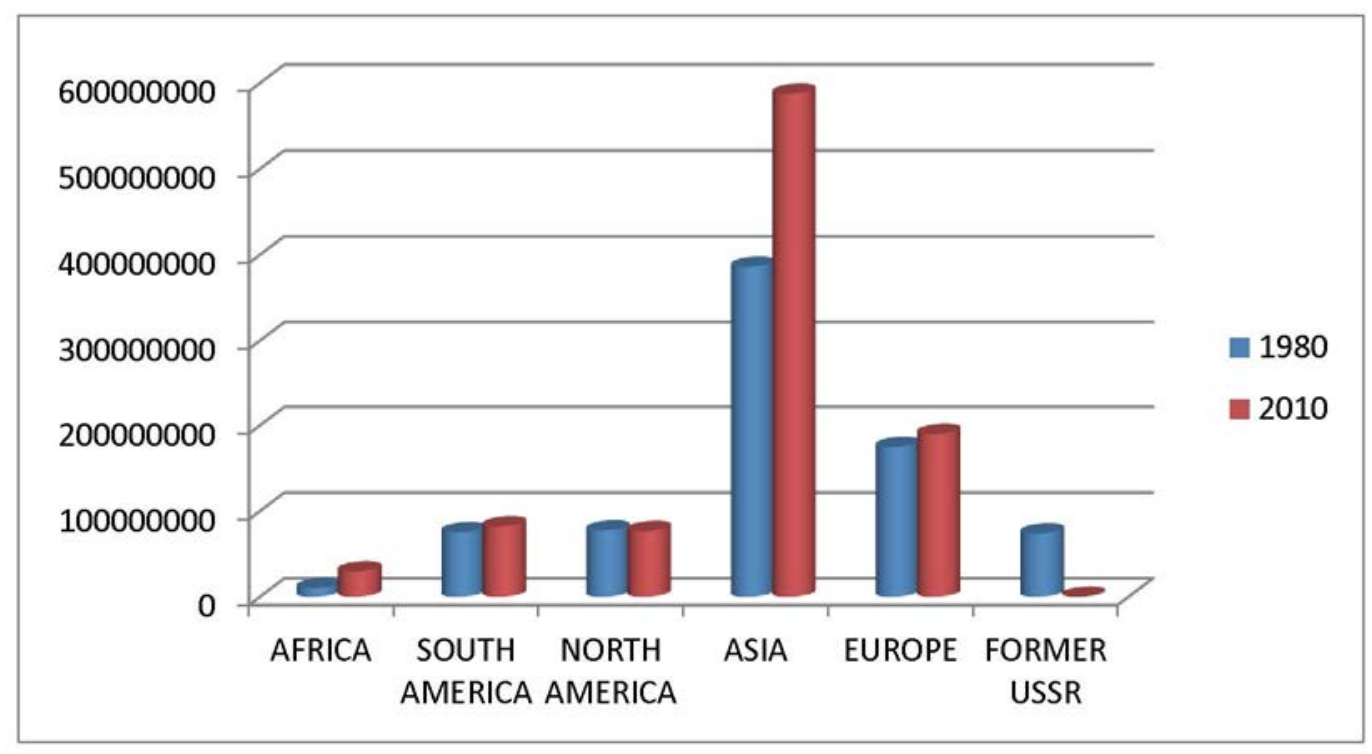




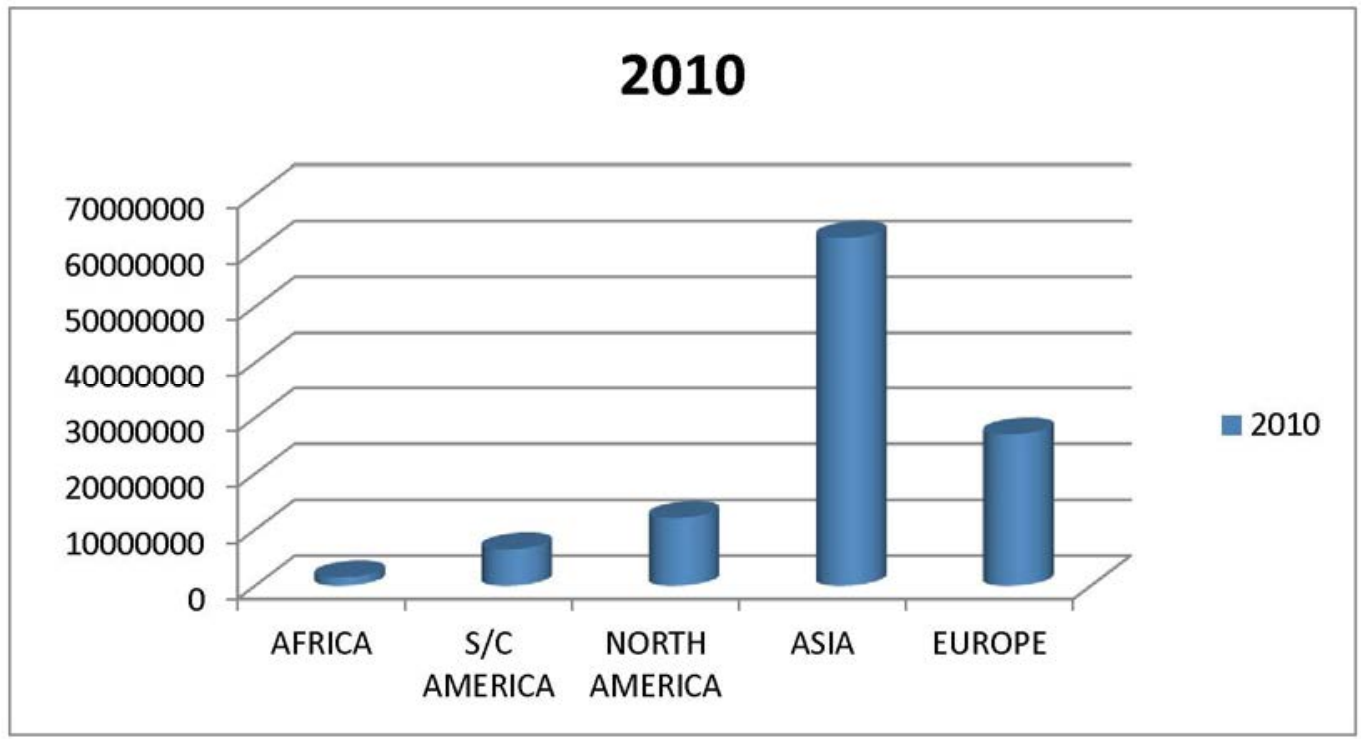




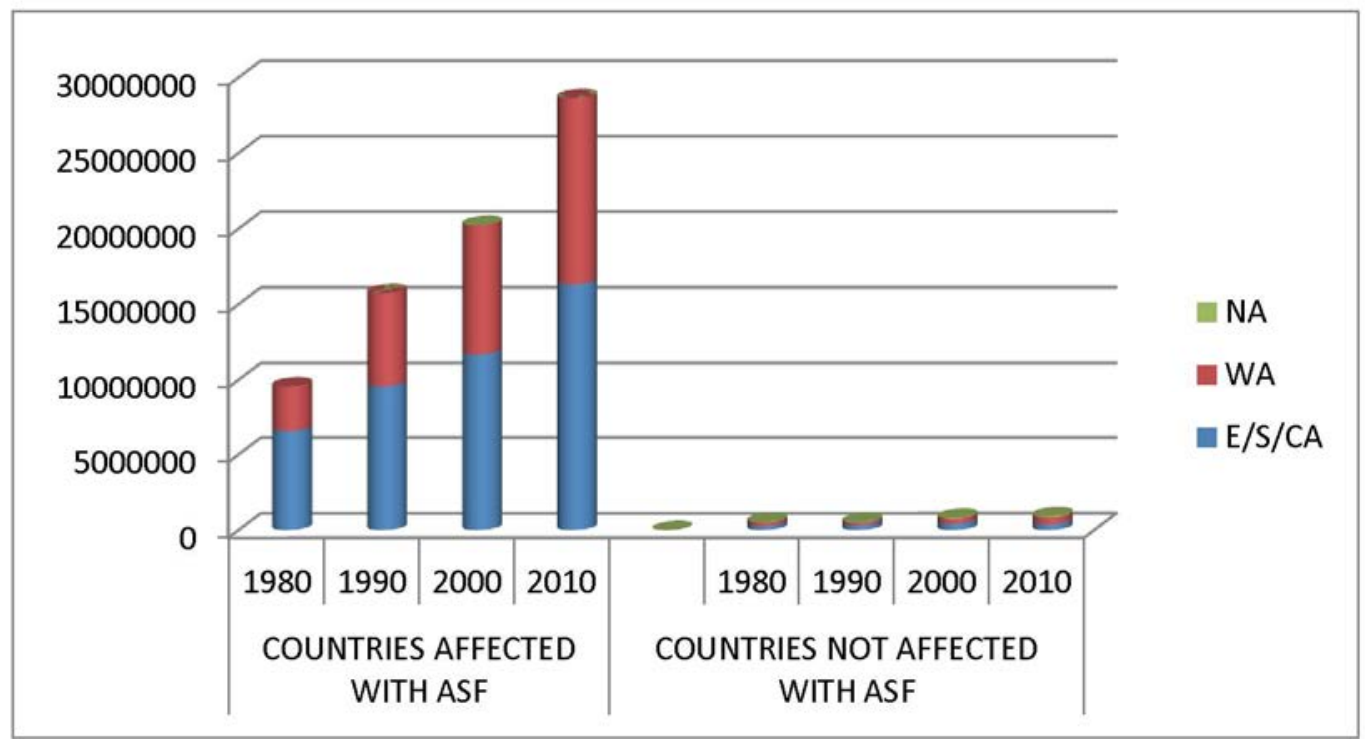




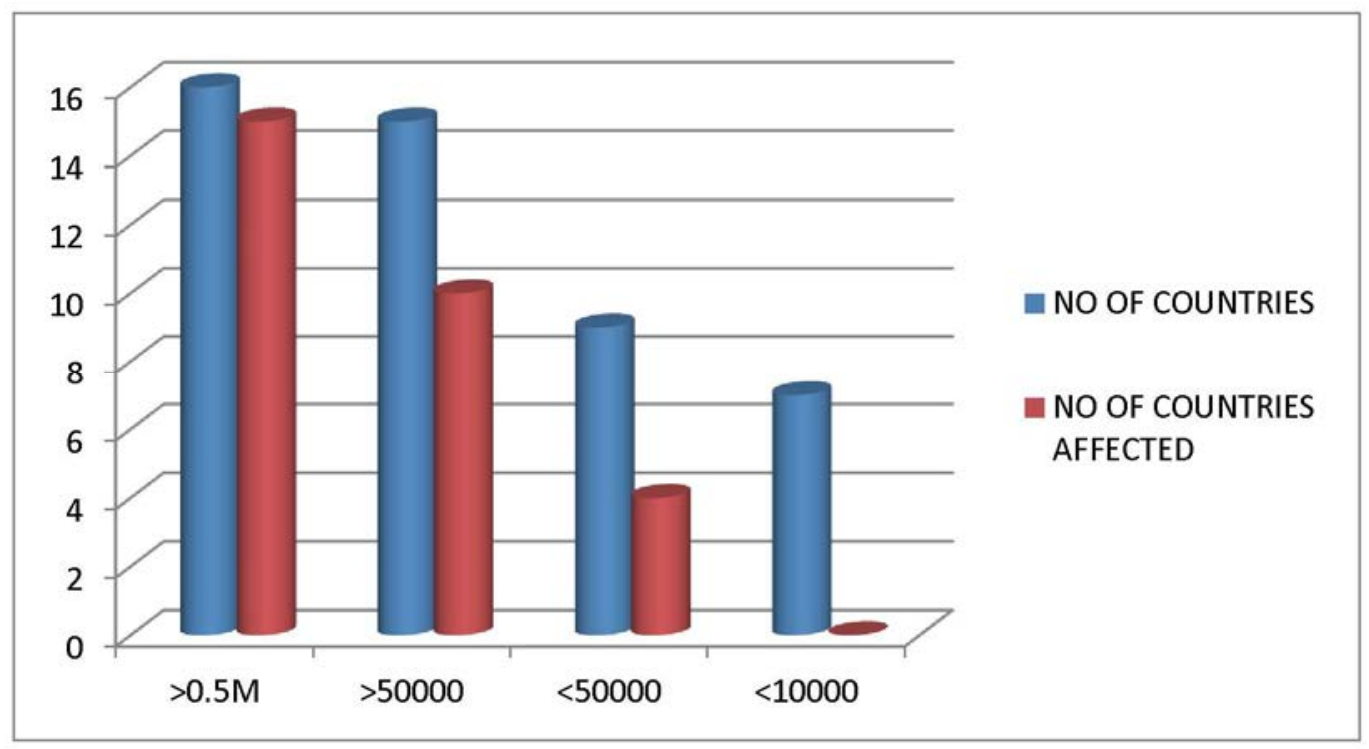




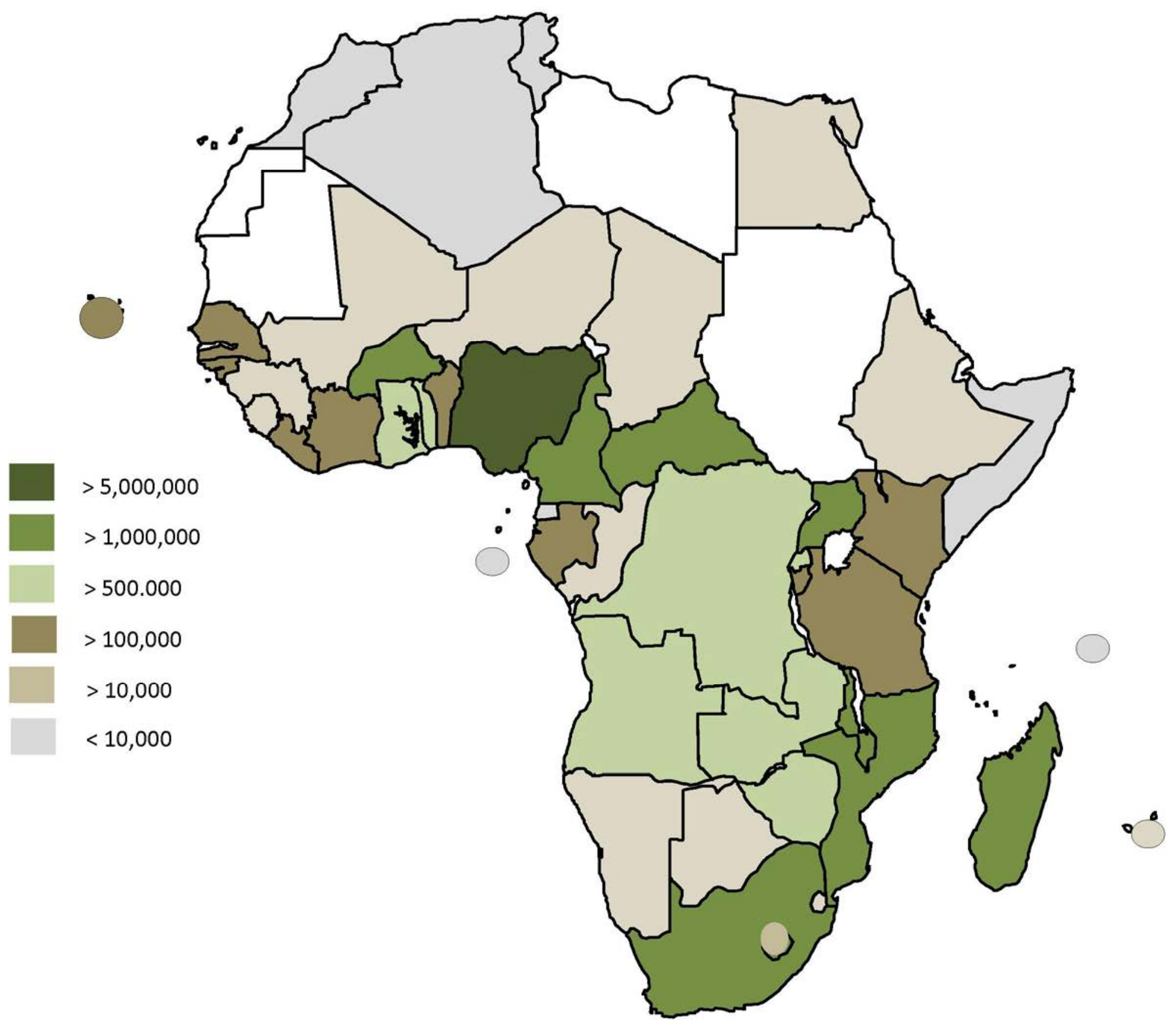




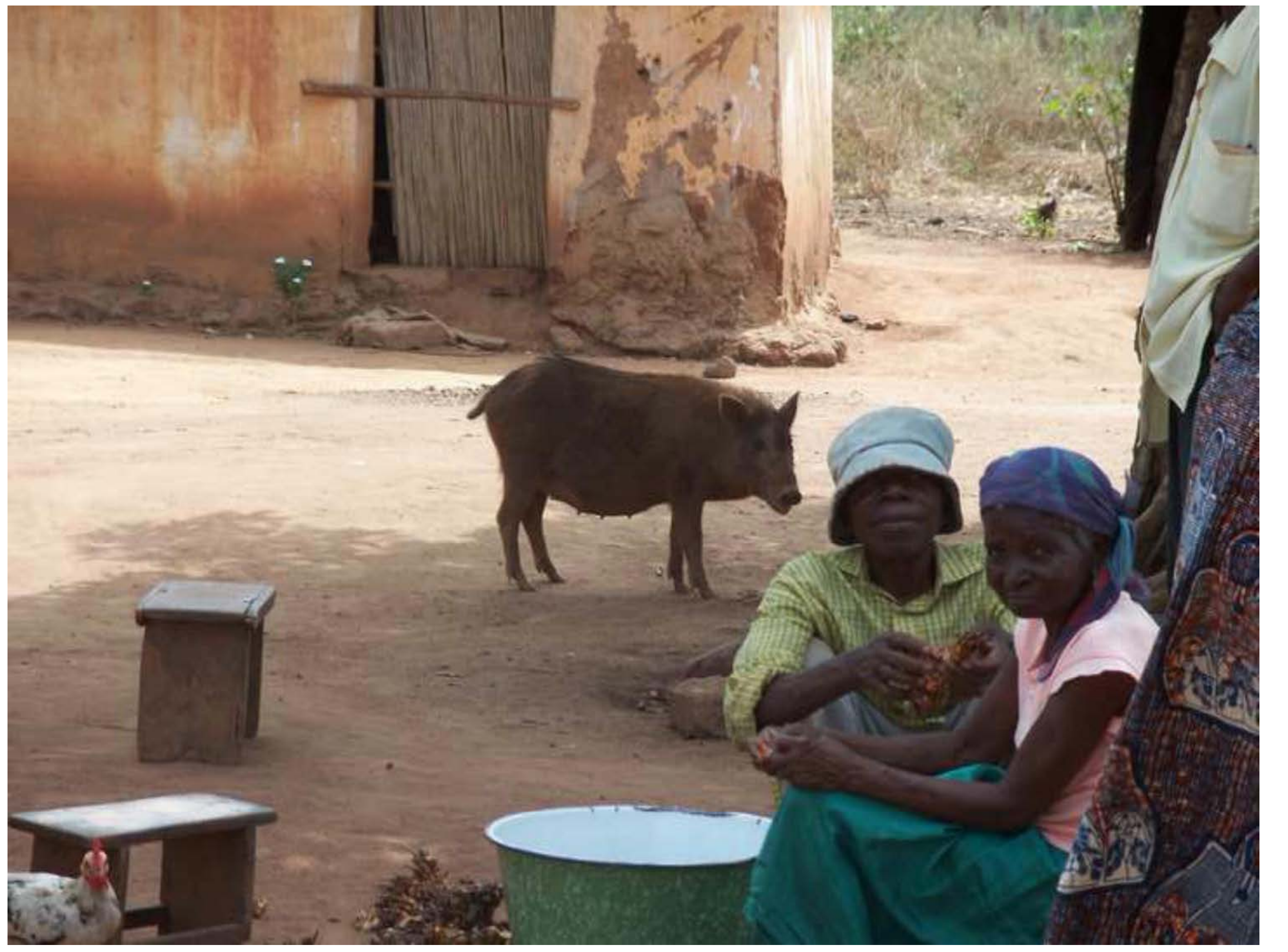




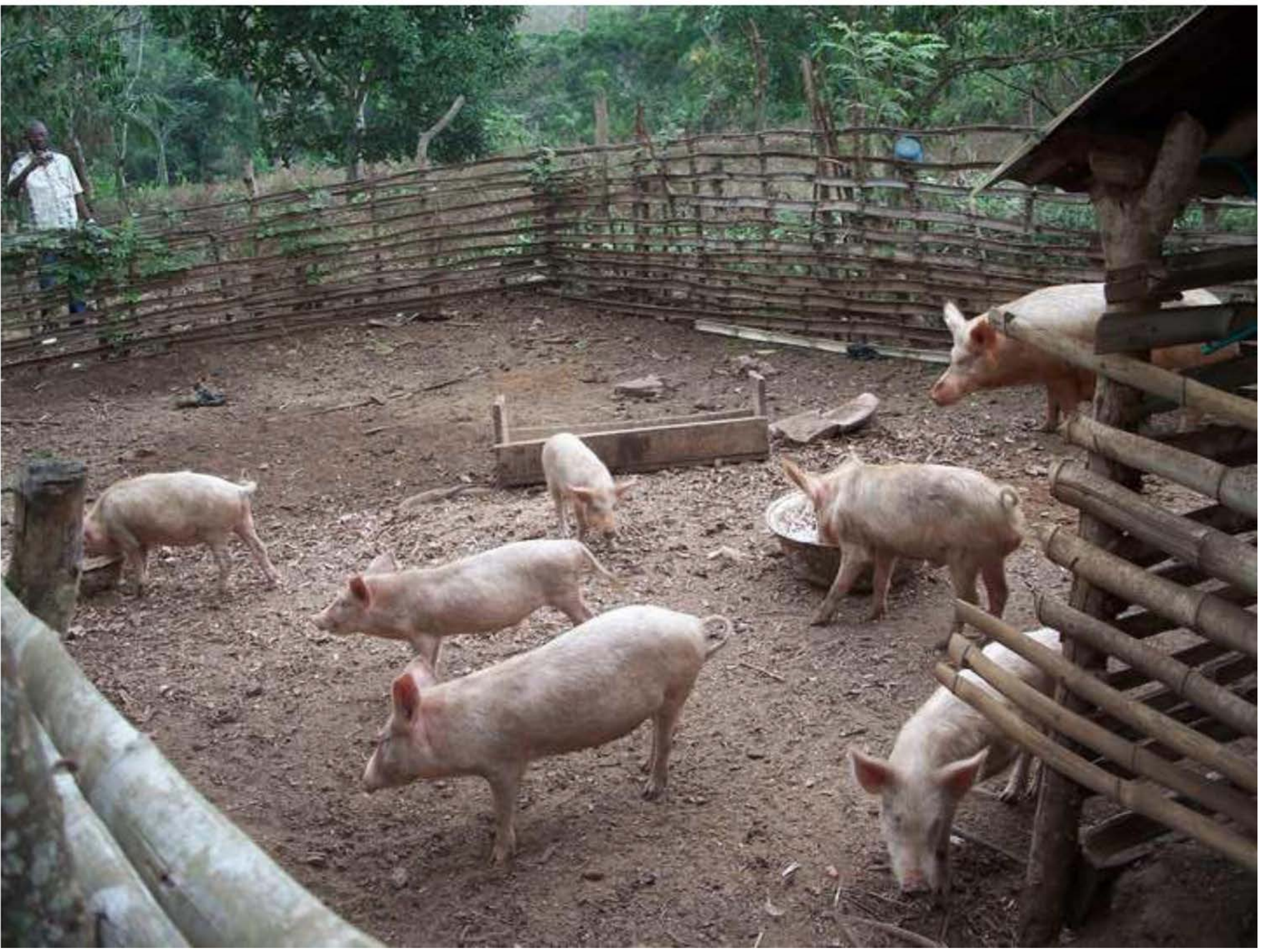


20 ar

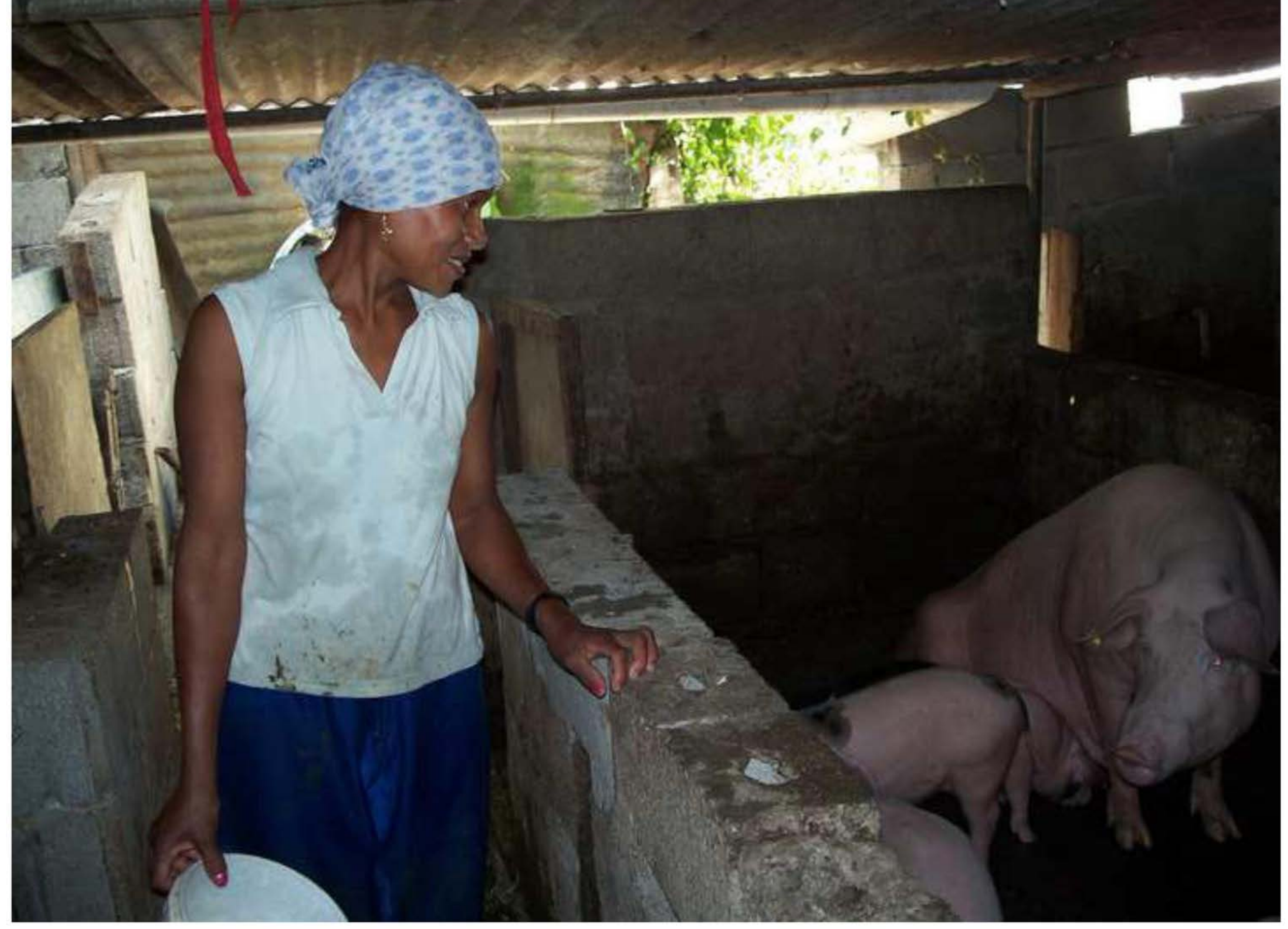




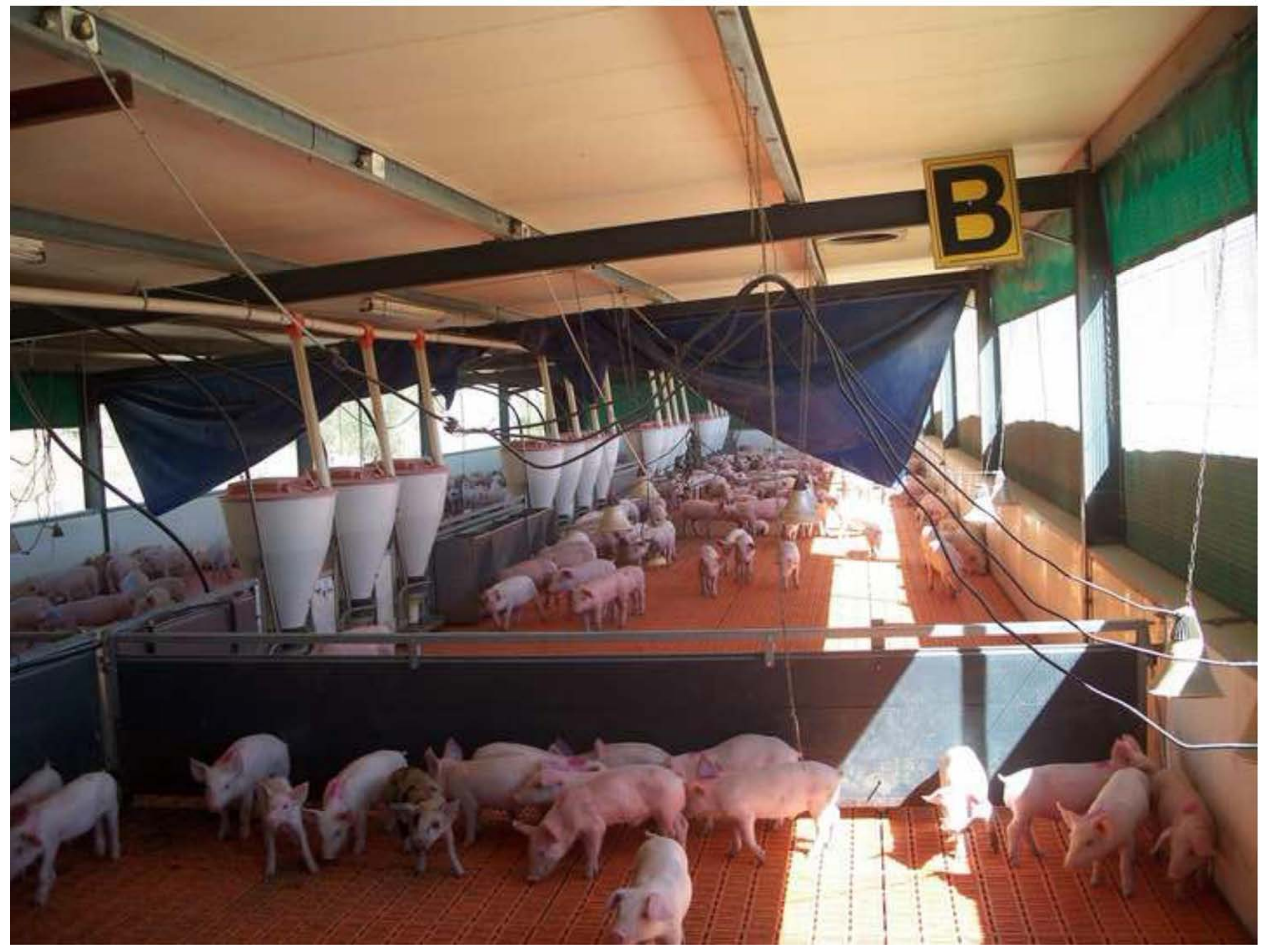




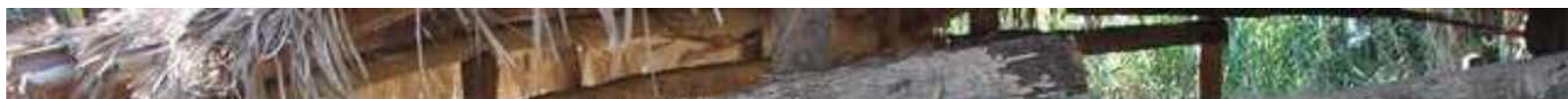

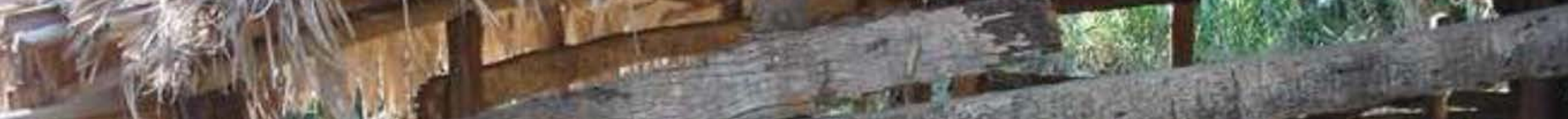

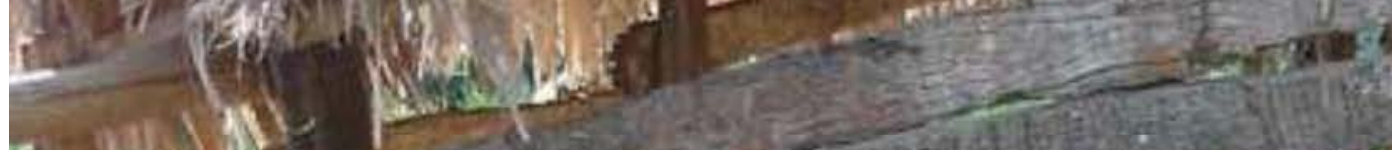

gingerse

in 10.25

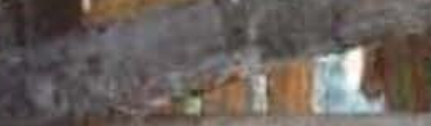

et

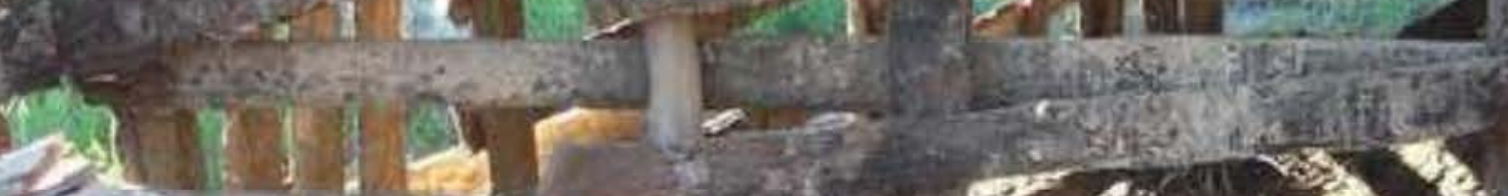

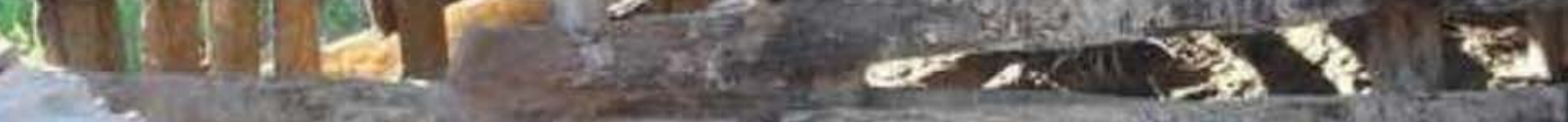

In

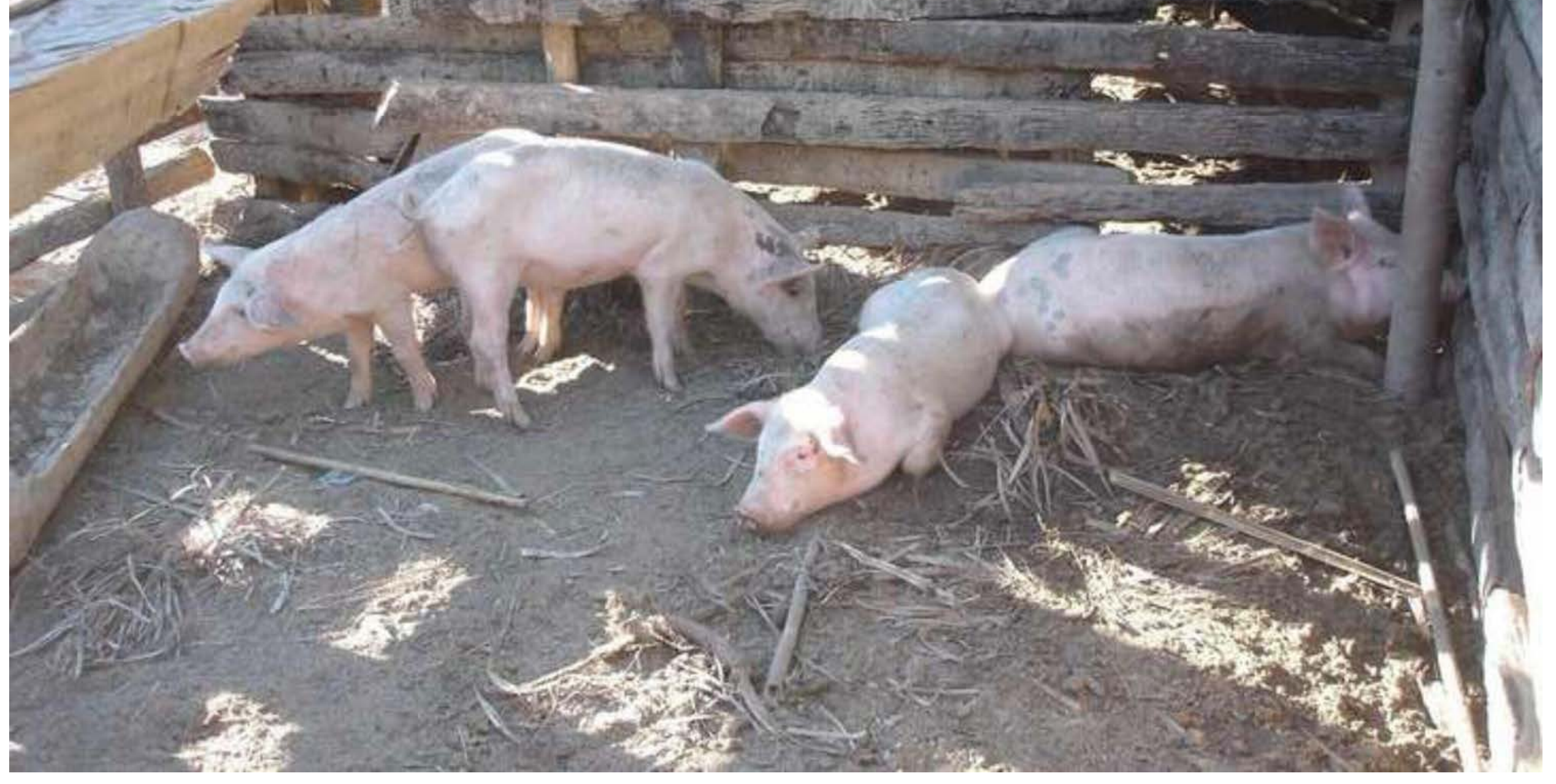




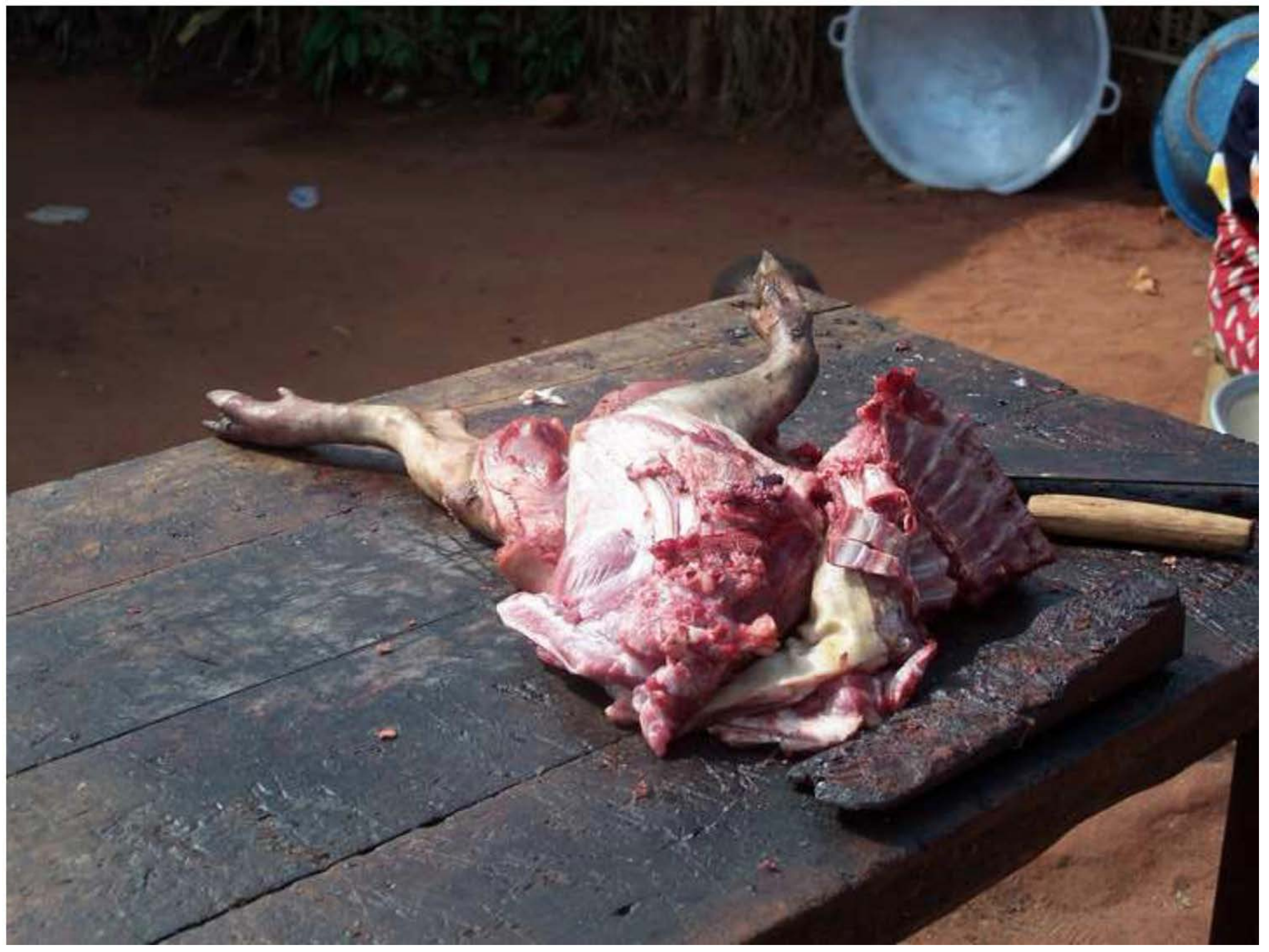




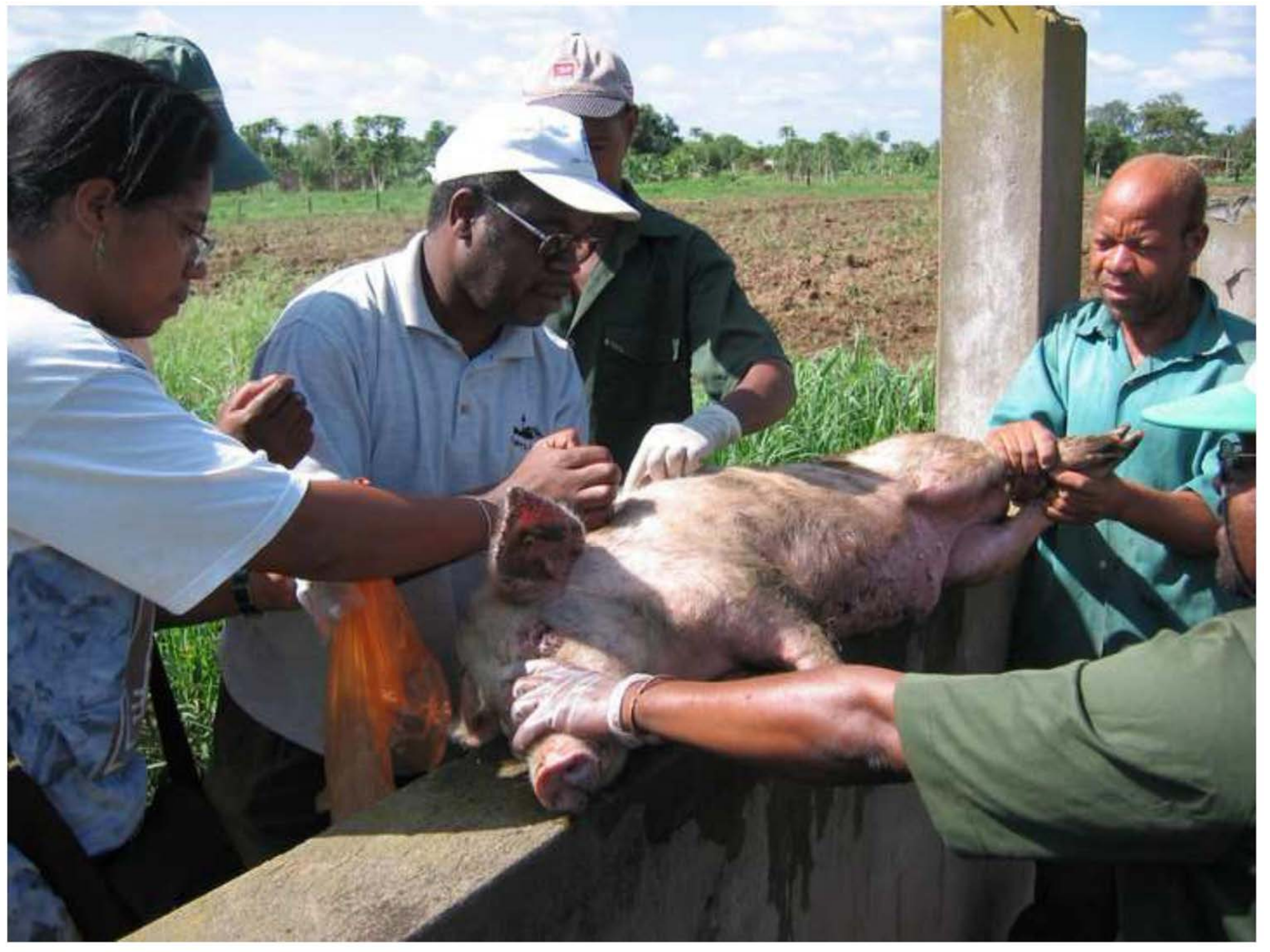

